\title{
EFFECT OF ROOF POND ON THE ENERGY AND EXERGY PERFORMANCE OF A SINGLE SPACE BUILDING
}

\author{
A. H. N. Khalifa ${ }^{1}$
}

\begin{abstract}
In a hot, arid zone, the load imposed on the building due to the roof is more than that for all the four walls; one of the proposed solutions to this condition is to use the roof pond. Using roof pond can reverse the performance of roof from heat source to heat sink that can withdraw the heat from building envelope. In this work a mathematical model, using the complex Fourier series was built for a single space building. Ambient temperature, solar radiation, and sol-air temperature have been treated as a periodic function of time. The effect of roof pond on the indoor temperature, heat flow to the building, temperature distribution through walls and roof were studied, as well as an exergy analysis to the roof pond was achieved. The result showed that using roof pond can reduce the mean indoor temperature by about $4{ }^{\circ} \mathrm{C}$ as compared with a building using the traditional roof. The exergy analysis showed that the maximum exergy efficiency conjunct with the maximum exergy destruction through roof pond.
\end{abstract}

\section{Keywords: Roof pond; Passive cooling; thermal analysis; Exergy analysis}

\section{INTRODUCTION}

Roof considered one of the major parts of the heat source to building enveloped during the summer season. Thus, it is recommended, especially in hot, arid zones, to store an amount of water in the form of pond above the exposed roof; this can help in mediate the room temperature by absorbing incident solar radiation on the roof by water. During night, water loses heat to the cold environment by convection and radiation. While through daytime, water still relatively cools, due to losing a part of absorbed heat by evaporation and radiation.

There are many works achieved on the roof pond. Sodha et al. [1] presented an analysis to reduce the heat flux through exposed roof by a constant flow of water in a network of pipes buried in a roof, a periodic solution of the one-dimensional partial differential equation was used. Sodha et al. [2] introduced a periodic analysis of the open roof pond, based on the linearization of Dunkle's expressions. Srivastava and Tiwari [3] have presented a periodic thermal model for an evaporative cooling system over the roof; three models were used, namely open roof pond, water film and flowing water layer over exposed roof. Tang and Etzion, [4] developed a simulation model to investigate and analysis of a roof pond with gunny bags floating on the water surface. In 2006, Kharrufa and Adil, [5] has examined two types of roof pond in Baghdad city, the first one is water in the pool with no fan and no cover while the second was with the pool and fan operational. The Performance of three passive cooling systems; namely, water pond on a roof, water jacket on roof and radiation shield on the roof were assessed experimentally and numerically by Sabzi et al.[6]. Hamdan and Al-Qudah, [7] have studied the performance of solar ponds with nanoparticles; the results obtained were compared with that without nanoparticles. Andan et al [8] have conduct an exergy based analysis for the building, for achieving thermal comfort of $23{ }^{\circ} \mathrm{C}$, inside the building envelope for the entire duration of 08:00 a.m. to 06:00 p.m. The analysis was further extended to the various wall insulation conditions for a building and a comparison of their performance with respect to the exergy and energy has been done.

In this work the performance of open roof pond works in Baghdad city at summer time was examined. Indoor, outdoor conditions, heat flux through walls and roof and the amount of evaporated water from the pond were set as a periodic function of time and solved by complex Fourier series. Indoor temperature and heat flux from walls and roof for a building with roof pond were compared with that of a building with a three-layered traditional roof. The Roof pond consists of water at a depth of $0.1 \mathrm{~m}$ followed by a concrete roof of $0.1 \mathrm{~m}$ thickness. The traditional roof is built from $0.025 \mathrm{~m}$ cement mortar, $0.1 \mathrm{~m}$ sand, and $0.1 \mathrm{~m}$ concrete roof. The outer walls of both buildings were built from $1 \mathrm{~cm}$ cement plaster, $0.24 \mathrm{~m}$ common brick and $5 \mathrm{~cm}$ gypsum plaster. Mathcad 15 software was used to solve the complex Fourier series. 


\section{THERMAL MODELING OF THE ROOF}

\section{Ambient conditions}

Ambient temperature, solar radiation and sol-air temperature can be assumed as periodic function of time; ambient temperature may write in the form of Fourier series as follows [9]:

$$
\mathrm{Tamb}_{\mathrm{t}}=\mathrm{To}+\sum_{\mathrm{t}=0}^{23} \mathrm{~T}_{\mathrm{m}} \cdot \mathrm{e}^{\mathrm{i} \cdot \mathrm{m} \cdot \omega \cdot \mathrm{t}}
$$

The constants of Fourier series of Equation (1) are as follow:

$$
\begin{aligned}
& \text { To }=\frac{1}{24} \sum_{\mathrm{t}=0}^{23} \mathrm{Tamb}_{\mathrm{t}} \\
& \mathrm{T}_{\mathrm{m}}=\mathrm{c} 1_{\mathrm{m}}-\mathrm{i} . \mathrm{c} 2_{\mathrm{m}}
\end{aligned}
$$

where:

$$
\begin{aligned}
& \mathrm{c} 1_{\mathrm{m}}=\frac{1}{12} \sum_{\mathrm{m}=1}^{6} \text { Tamb } \cdot \cos (\mathrm{m} \cdot \omega \cdot \mathrm{t}) \\
& \mathrm{c} 2_{\mathrm{m}}=\frac{1}{12} \sum_{\mathrm{m}=1}^{6} \text { Tamb } \cdot \sin (\mathrm{m} \cdot \omega \cdot \mathrm{t})
\end{aligned}
$$

In the same manner, solar intensity in the form of Fourier series is:

$$
I S_{j, t}=I_{j}+\sum_{m=1}^{6} I_{j, m} \cdot e^{i . m . \omega t}
$$

Since the outer surface of building structure submitted to solar radiation as well as ambient temperature, so, the use of ambient temperature alone in calculating room load is not accurate. Thus, the use of sol-air temperature is more reasonable in calculating the room load. Sol-air temperature can be written as [10].

$$
\mathrm{Ts}_{\mathrm{j}, \mathrm{t}}=\mathrm{Tamb}_{\mathrm{t}}+\frac{\alpha_{\mathrm{j}} \cdot \mathrm{I}_{\mathrm{j}, \mathrm{t}}}{\mathrm{h}_{1}}-\frac{\varepsilon_{\mathrm{j}} \cdot \Delta \mathrm{R}_{\mathrm{j}}}{\mathrm{h}_{1}}
$$

After calculation the soil-air temperature, it can be change to a periodic function of time. The sol-air for building walls and roof in form of periodic function of time, as follow:

$$
\mathrm{Tsol}_{\mathrm{j}, \mathrm{t}}=\mathrm{Ts}_{\mathrm{j}}+\sum_{\mathrm{m}=1}^{6} \mathrm{Ts} s_{\mathrm{j}, \mathrm{m}} \cdot \mathrm{e}^{\mathrm{i} . \mathrm{m} \cdot \omega \mathrm{t}}
$$

\section{ROOF POND}

Open roof pond was placed over a concrete roof of thickness X, the boundary conditions for the roof pond that shown in Figure 1, are as follow:

at $\mathrm{x}=0$

$$
-\left.\mathrm{k} \cdot \frac{\mathrm{dTr} r_{\mathrm{x}, \mathrm{t}}}{\mathrm{dx}}\right|_{\mathrm{x}=0}=\alpha \cdot \mathrm{IS}_{4, \mathrm{t}}-\mathrm{h}_{4} \cdot\left(\operatorname{Tr}_{(\mathrm{x}=0, \mathrm{t})}-\mathrm{Tw}_{\mathrm{t}}\right)
$$

The temperature distribution through concrete roof $\operatorname{Tr}_{(\mathrm{x}=0, \mathrm{t})}$ is written as periodic function as: 


$$
\operatorname{Tr}_{(x, t)}=A 1 \cdot x+B 1+\sum_{m=1}^{6}\left(A 1_{m} e^{\beta_{m} \cdot x} \cdot+B 1_{m} e^{-\beta_{m} \cdot x}\right) e^{i \cdot m \cdot \omega t}
$$

The variables $\beta_{\mathrm{m}}$ equals to:

$$
\beta_{m}=\sqrt{\frac{i . m \cdot \omega \cdot \rho_{R} \cdot c_{R}}{k_{R}}}
$$

Water temperature $\mathrm{Tw}_{\mathrm{t}}$ is a periodic function of time, and can be written as:

$$
\mathrm{Tw}_{\mathrm{t}}=\mathrm{A} 2+\sum_{\mathrm{m}=1}^{6} \mathrm{~B} 2_{\mathrm{m}} \cdot \mathrm{e}^{\mathrm{i} \cdot \mathrm{m} \cdot \omega \mathrm{t}}
$$

at $\mathrm{x}=\mathrm{X}$

$$
-\left.\mathrm{k} \cdot \frac{\mathrm{dTr}}{\mathrm{dx}, \mathrm{t}}\right|_{\mathrm{x}=\mathrm{x}}=\mathrm{h}_{2}\left(\left(\operatorname{Tr}_{(\mathrm{x}=\mathrm{x}, \mathrm{t})}-\operatorname{Tin}_{\mathrm{t}}\right)\right.
$$

Where $\operatorname{Tin}_{t}$ is the inside temperature of the unconditioned building, and can be writing as:

$$
\operatorname{Tin}_{\mathrm{t}}=\mathrm{A} 3+\sum_{\mathrm{m}=1}^{6} \mathrm{~B} 3_{\mathrm{m}} \cdot \mathrm{e}^{\mathrm{i} \cdot \mathrm{m} \cdot \omega \mathrm{t}}
$$

The thermal balance of the water in roof pond is:

$$
\begin{gathered}
\mathrm{m}_{\mathrm{w}} \cdot \mathrm{c}_{\mathrm{w}} \cdot \frac{\mathrm{dTw}}{\mathrm{dt}}=\operatorname{AR} \cdot\left[\tau_{\mathrm{w}} \cdot \mathrm{IS}_{4, \mathrm{t}}-\mathrm{h}_{4} \cdot\left(\operatorname{Tr}_{(\mathrm{x}=0, \mathrm{t})}-\mathrm{Tw}_{\mathrm{t}}\right)-\mathrm{h}_{5} \cdot\left(\mathrm{Tw}_{\mathrm{t}}-\operatorname{Tamb}_{\mathrm{t}}\right)\right. \\
\left.-\mathrm{h}_{6} \cdot\left(\mathrm{Tw}_{\mathrm{t}}-\mathrm{Tamb}_{\mathrm{t}}\right)-\mathrm{h}_{7} \cdot\left(\mathrm{p}_{\mathrm{v}} \cdot \mathrm{Tw}_{\mathrm{t}}-\emptyset \cdot \mathrm{p}_{\mathrm{v}} \cdot \operatorname{Tamb}_{\mathrm{t}}\right)\right]
\end{gathered}
$$

The method of calculating the convection, evaporation and radiation heat transfer coefficients mentioned above will be shown later.

The time independent constants namely, $\mathrm{A} 1$, to $\mathrm{A} 3 \mathrm{~B} 1$ to $\mathrm{B} 3$, and time dependent constants $\mathrm{A} 1_{\mathrm{m}}$ to $\mathrm{A} 3_{\mathrm{m}}$ and $\mathrm{B} 1_{\mathrm{m}}$ to $\mathrm{B} 3_{\mathrm{m}}$ to be found as follows:

The differentiation of Equation (5) is:

$$
-k \cdot\left(B 1+\beta_{m} \cdot A 1_{m}-\beta_{m} \cdot B 1_{m}\right)=\alpha \cdot\left(I_{4}+I_{4, m}\right)-h_{4} \cdot\left(B 1+A 1_{m}+B 1_{m}-A 2-B 2_{m}\right)
$$

Equation (5.1) can be separated into two equations; the first one is time independent equation:

$$
-\mathrm{k} . \mathrm{B} 1=\alpha \cdot \mathrm{I}_{4}-\mathrm{h}_{4} \cdot(\mathrm{B} 1-\mathrm{A} 2)
$$

And the time dependent equation is:

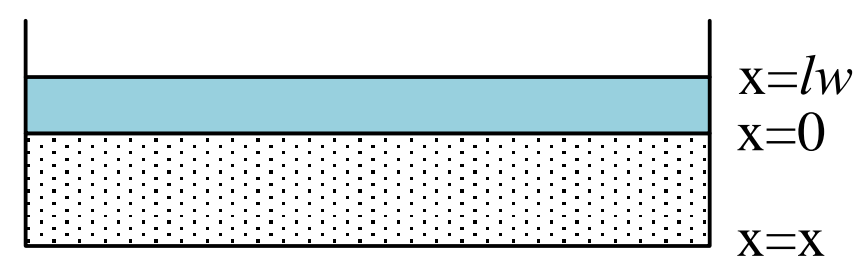

Figure 1. Roof pond construction 


$$
-\mathrm{k} \cdot\left(\beta_{\mathrm{m}} \cdot \mathrm{A} 1_{\mathrm{m}}-\beta_{\mathrm{m}} \cdot \mathrm{B} 1_{\mathrm{m}}\right)=\alpha \cdot \mathrm{I}_{4, \mathrm{~m}}-\mathrm{h}_{4} \cdot\left(\mathrm{A} 1_{\mathrm{m}}+\mathrm{B} 1_{\mathrm{m}}-\mathrm{B} 2_{\mathrm{m}}\right)
$$

After differentiation Equation (9), the time independent and dependent equations are:

$$
\begin{gathered}
-k \cdot(A 1 \cdot x+B 1)=h_{2} \cdot(A 1 \cdot x+B 1-A 3) \\
-k \cdot\left(A 1_{m} \cdot \beta_{m} \cdot e^{\beta_{m} \cdot x} \cdot+B 1_{m} \cdot \beta_{m} \cdot e^{-\beta_{m} \cdot x}\right)=h_{2} \cdot\left(A 1_{m} e^{\beta_{m} \cdot x}+B 1_{m} e^{-\beta_{m} \cdot x}-B 3_{m}\right)
\end{gathered}
$$

The terms of equation (11) are either time independent or time dependent, and therefore can be separated into two groups which should essentially be equal to a constant value. It was decided to assign an arbitrary value of zero to the time independent term, since it has no effect on the relative physical behavior of the time dependent group.

$$
\begin{aligned}
& 0=\operatorname{AR}\left[\tau_{\mathrm{w}} \cdot \mathrm{I}_{4}-\mathrm{h}_{4} \cdot(B 1-\mathrm{A} 2)-\left(\mathrm{h}_{5}+\mathrm{h}_{6}\right) \cdot(\mathrm{A} 2-\mathrm{To})-\mathrm{h}_{7} \cdot\left(\mathrm{p}_{\mathrm{v}} \cdot \mathrm{A} 2-\emptyset \cdot \mathrm{p}_{\mathrm{v}} \cdot \mathrm{To}\right)\right] \\
& \begin{aligned}
\text { i. } \mathrm{m} . \omega \mathrm{m}_{\mathrm{w}} \cdot \mathrm{c}_{\mathrm{w}}=\operatorname{AR}\left[\tau_{\mathrm{w}} \cdot \mathrm{I}_{4, \mathrm{~m}}-\mathrm{h}_{4} \cdot\left(\mathrm{A} 1_{\mathrm{m}}+\mathrm{B} 1_{\mathrm{m}}-\mathrm{B} 2_{\mathrm{m}}\right)-\left(\mathrm{h}_{5}+\mathrm{h}_{6}\right) \cdot\left(\mathrm{B} 2_{\mathrm{m}}-\mathrm{T}_{\mathrm{m}}\right)\right. \\
\left.-\mathrm{h}_{7} \cdot\left(\mathrm{p}_{\mathrm{v}} \cdot \mathrm{B} 2_{\mathrm{m}}-\emptyset \cdot \mathrm{p}_{\mathrm{v}} \mathrm{T}_{\mathrm{m}}\right)\right]
\end{aligned}
\end{aligned}
$$

By solving equations (5-1a), (5-1b), (9.1a), (9.1b), (11.1a) and (11.1b), the time dependent and independent constants can be found, as shown in appendix (1).

The heat flow to the room from inner surface of the roof is:

$$
\operatorname{Qroof}_{\mathrm{t}}=\mathrm{h} 2_{4} \cdot \operatorname{AR}\left(\operatorname{Tr}_{(\mathrm{x}=x, \mathrm{t})}-\operatorname{Tin}_{\mathrm{t}}\right)
$$

Substituting Equations (6) and (8) in Equation (12) and rearrange yields:

$$
\text { Qroof }_{\mathrm{t}}=\text { UR. AR }\left(\frac{\mathrm{B} 1-\mathrm{A} 3}{\frac{1}{\mathrm{~h}_{2}}+\frac{\mathrm{x}}{\mathrm{x}}}\right)+\text { UR.AR. } \sum_{\mathrm{m}=1}^{6}\left(\mathrm{~N} 6_{\mathrm{m}} \cdot \mathrm{I}_{4, \mathrm{~m}}+\mathrm{R} 7_{\mathrm{m}} \cdot \mathrm{T}_{\mathrm{m}}-\mathrm{F} 7_{\mathrm{m}} \mathrm{B} 3_{\mathrm{m}}\right) \cdot \mathrm{e}^{\text {i.m. } \omega \mathrm{t}}
$$

\section{WALLS AND TRADITIONAL ROOF}

The walls and the traditional roof are assumed to be consists of three layers, as shown in Figure 2. The periodic temperature distribution through walls and roof layers are:

$$
\begin{aligned}
& \mathrm{TW} 1_{j, \mathrm{t}}=\mathrm{E} 1_{\mathrm{j}} \cdot \mathrm{x} 1_{\mathrm{j}}+\mathrm{P} 1_{\mathrm{j}}+\sum_{\mathrm{m}=1}^{6}\left(\mathrm{E} 1_{\mathrm{m}} \mathrm{e}^{\gamma 1_{\mathrm{j}, \mathrm{m}} \cdot \mathrm{x} 1_{\mathrm{j}}}+\mathrm{P} 1_{\mathrm{m}} \mathrm{e}^{-\gamma 1_{\mathrm{j}, \mathrm{m}} \cdot \mathrm{x} 1_{\mathrm{j}}}\right) \mathrm{e}^{\mathrm{i} . \mathrm{m} \cdot \omega \mathrm{t}} \\
& T W 2_{j, t}=E 2_{j} \cdot x 2_{j}+P 2_{j}+\sum_{m=1}^{6}\left(E 2_{m} e^{\gamma 2_{j}, m \cdot x 2_{j}} \cdot+P 2_{m} e^{-\gamma 2_{j}, m \cdot x z_{j}}\right) e^{i . m . \omega t} \\
& T W 3_{j, t}=E 3_{j} \cdot x 3_{j}+P 3_{j}+\sum_{m=1}^{6}\left(E 3_{m} e^{\gamma 3_{j}, m \cdot x 3_{j}} \cdot+P 3_{m} e^{-\gamma 3_{j}, m \cdot x 3_{j}}\right) e^{i . m . \omega t}
\end{aligned}
$$

where:

$$
\gamma 1_{j, m}=\sqrt{\frac{i . m \cdot \omega \cdot \rho 1_{j} \cdot c 1_{j}}{k 1_{j}}}
$$




$$
\begin{aligned}
& \gamma 2_{j, m}=\sqrt{\frac{i \cdot m \cdot \omega \cdot \rho 2_{j} \cdot c 2_{j}}{k 2_{j}}} \\
& \gamma 3_{j, m}=\sqrt{\frac{i \cdot m \cdot \omega \cdot \rho 3_{j} \cdot c 3_{j}}{k 3_{j}}}
\end{aligned}
$$

Walls and roof boundary conditions:

at $\mathrm{x}=0$

$$
-\left.\mathrm{k} 1_{\mathrm{j}} \frac{\mathrm{dTW} 1_{\mathrm{j}, \mathrm{t}}}{\mathrm{dx}}\right|_{\mathrm{x}=0}=\mathrm{h} 1 .\left(\operatorname{Tsol}_{\mathrm{j}, \mathrm{t}}-\mathrm{TW} 1_{\mathrm{j}, \mathrm{t}}\right)
$$

At $x=x 1 j$

At $x=x 2 j$

$$
\begin{aligned}
-\left.\mathrm{k} 1_{\mathrm{j}} \frac{\mathrm{dTW} 1_{\mathrm{j}, \mathrm{t}}}{\mathrm{dx}}\right|_{\mathrm{x}=\mathrm{x} 1_{\mathrm{j}}} & =-\left.\mathrm{k} 2_{\mathrm{j}} \frac{\mathrm{dTW} 2_{\mathrm{j}, \mathrm{t}}}{\mathrm{dx}}\right|_{\mathrm{x}=\mathrm{x} 1_{\mathrm{j}}} \\
\left.\mathrm{TW} 1_{\mathrm{j}, \mathrm{t}}\right|_{\mathrm{x}=\mathrm{x} 1_{\mathrm{j}}} & =\left.\mathrm{TW} 2_{\mathrm{j}, \mathrm{t}}\right|_{\mathrm{x}=\mathrm{x} 1_{j}}
\end{aligned}
$$

At $x=x 3 j$

$$
\begin{gathered}
-\left.\mathrm{k} 2_{\mathrm{j}} \frac{\mathrm{dTW} 2_{\mathrm{j}, \mathrm{t}}}{\mathrm{dx}}\right|_{\mathrm{x}=\mathrm{x} 2_{j}}=-\left.\mathrm{k} 3_{\mathrm{j}} \frac{\mathrm{dTW} 3_{\mathrm{j}, \mathrm{t}}}{\mathrm{dx}}\right|_{\mathrm{x}=\mathrm{x} 2_{\mathrm{j}}} \\
\left.\mathrm{TW} 2_{\mathrm{j}, \mathrm{t}}\right|_{\mathrm{x}=\mathrm{x} 2_{\mathrm{j}}}=\left.\mathrm{TW} 3_{\mathrm{j}, \mathrm{t}}\right|_{\mathrm{x}=\mathrm{x} 2_{\mathrm{j}}}
\end{gathered}
$$

$$
-\left.\mathrm{k} 3_{\mathrm{j}} \frac{\mathrm{dTW} 3_{\mathrm{j}, \mathrm{t}}}{\mathrm{dx}}\right|_{\mathrm{x}=\mathrm{x} 3_{\mathrm{j}}}=\mathrm{h} 2_{\mathrm{j}} \cdot\left(\mathrm{TW} 3_{\mathrm{j}, \mathrm{t}}-\operatorname{Tin}_{\mathrm{t}}\right)
$$

Differentiate Equations (18 to 21) and separated them into time dependent and independent equations, the constants E1, E2, E3, P1, P2, P3, E1m, E2m, E3m, P1m, P2m and P3m can be found as shown in appendix (2). Heat flow through walls and roof from the inner surface of the building construction to the room equals to:

$$
\frac{\text { Qwall }}{\text { roof }}_{\mathrm{j}, \mathrm{t}}=\mathrm{h} 2_{\mathrm{j}} \mathrm{AW}_{\mathrm{j}} \cdot\left(\mathrm{TW} 3_{\mathrm{j}, \mathrm{t}}-\mathrm{Tin}_{\mathrm{t}}\right)
$$

Substituting Equations (10) and (14.3) into Equation (22) and rearrange yields:

$$
\text { Qwall/roof } f_{j, t}=U_{j} \cdot A W_{j} \cdot\left(T_{j}-A 3\right)+A W_{j} \cdot . \sum_{m=1}^{6}\left(B T 11_{m} \cdot B 3_{m}+B T 12_{j, m} T s_{j, m}\right) \cdot e^{i \cdot m \cdot \omega t}
$$

\section{HEAT FLOW DUE TO FENESTRATION AND VENTILATION}

Heat flow through window due to solar radiation equals:

$$
\text { Qglass }_{\mathrm{j}, \mathrm{t}}=\tau_{\mathrm{g}} \cdot \operatorname{Ag}_{\mathrm{j}} \cdot \mathrm{IS}_{\mathrm{j}, \mathrm{t}}-\mathrm{h}_{3} \cdot\left(\operatorname{Tin}_{\mathrm{t}}-\operatorname{Tamb}_{\mathrm{t}}\right)
$$


Heat flow due to ventilation is:

$$
\text { Qvent }_{\mathrm{t}}=\dot{\mathrm{m}}_{\mathrm{vent}} \cdot \mathrm{c}_{\mathrm{a}} \cdot\left(\operatorname{Tin}_{\mathrm{t}}-\mathrm{Tamb}_{\mathrm{t}}\right)-\dot{\mathrm{m}}_{\mathrm{vent}} \cdot \Delta \mathrm{g} \cdot \mathrm{hfg}
$$

Equations (24) and (25) can be solved by substitution of indoor and ambient temperature as mentioned above.

The constants of the Equation (10) that represent the indoor temperature, namely A3 and A3m are as follows:

a- For building with roof pond:

$$
\begin{aligned}
& A 3_{m}=\frac{C 1+C 2}{m_{a} \cdot c_{a} \cdot \omega \cdot m-U R \cdot A R \cdot F 7_{m}+h_{3} \cdot A g_{j}+2501 \cdot \dot{m}_{v e n t} \cdot \Delta g-\sum_{j=0}^{3}\left(A w_{j} \cdot B T 11_{j, m}\right)} \\
& \mathrm{C} 1=\text { UR. AR. } \mathrm{I}_{4, \mathrm{~m}}+\text { UR. AR. } \mathrm{R} 7_{\mathrm{m}} \cdot \mathrm{T}_{\mathrm{m}}+\mathrm{h}_{3} \cdot \mathrm{Ag}_{\mathrm{j}} \cdot \mathrm{T}_{\mathrm{m}} \\
& \mathrm{C} 2=2501 \cdot \dot{\mathrm{m}}_{\mathrm{vent}} \cdot \Delta \mathrm{g} \cdot \mathrm{T}_{\mathrm{m}}+\alpha_{\mathrm{g}} \cdot \tau_{\mathrm{g}} \cdot \mathrm{I}_{\mathrm{j}, \mathrm{m}} \cdot \mathrm{Ag}_{\mathrm{j}}+\sum_{\mathrm{j}=0}^{3}\left(\mathrm{Aw}_{\mathrm{j}} \cdot \mathrm{BT} 12_{\mathrm{j}, \mathrm{m}} \cdot \mathrm{I}_{\mathrm{j}, \mathrm{m}}\right) \\
& \mathrm{A} 3=\frac{\sum_{\mathrm{j}=0}^{3}\left(\mathrm{UW}_{\mathrm{j}} \cdot \mathrm{AW}_{\mathrm{j}} \mathrm{I}_{\mathrm{j}}\right)+\text { UR. AR. C3. To }+\left(2501 \cdot \dot{\mathrm{m}}_{\text {vent }} \cdot \Delta \mathrm{g}\right) \cdot \mathrm{To}+\tau_{\mathrm{g}} \cdot \mathrm{I}_{\mathrm{j}, \mathrm{m}} \cdot \mathrm{Ag}_{\mathrm{j}}}{\text { UR. AR }+\mathrm{h}_{3} \cdot A g_{\mathrm{j}}+2501 \cdot \dot{\mathrm{m}}_{\text {vent }} \cdot \Delta \mathrm{g}_{\mathrm{h}_{3}}+\sum_{\mathrm{j}=0}^{3} \mathrm{UW}_{\mathrm{j}} \cdot \mathrm{AW}_{\mathrm{j}}}
\end{aligned}
$$

Where:

$$
\begin{gathered}
\text { C3 }=\frac{\left(\tau_{\mathrm{w}}-\alpha . . \mathrm{UR} \cdot\left(\frac{1}{\mathrm{~h}_{2,}}+\frac{\mathrm{x}}{\mathrm{kR}}\right)\right) \cdot \mathrm{I}_{4}+\left(\mathrm{h}_{5}+\mathrm{h}_{6}+\emptyset \cdot . \mathrm{p}_{\mathrm{v}} \mathrm{h}_{7}\right)}{\left(\mathrm{h}_{4}+\mathrm{h}_{5}+\mathrm{h}_{6}+\mathrm{p}_{\mathrm{v}} \cdot \mathrm{h}_{7}\right)-\mathrm{UR} \cdot\left(\frac{1}{\mathrm{~h}_{2}}+\frac{\mathrm{x}}{\mathrm{kR}}\right) \cdot \mathrm{h}_{4}} \\
\frac{1}{\mathrm{UR}}=\frac{1}{\mathrm{~h}_{4}}+\frac{1}{\mathrm{~h}_{2,4}}+\frac{\mathrm{x}}{\mathrm{kR}}
\end{gathered}
$$

b- For building with traditional roof:

$$
\begin{gathered}
A 3_{m}=\frac{h_{3} \cdot A g_{j} \cdot T_{m}+2501 \cdot \dot{m}_{v e n t} \cdot \Delta g \cdot T_{m}+\tau_{g} \cdot I_{j, m} \cdot A g_{j}+\sum_{j=0}^{4}\left(A w_{j} \cdot B T 12_{j, m} \cdot I_{j, m}\right)}{m_{a} \cdot c_{a} \cdot \omega \cdot m+h_{3} \cdot A g_{j}+2501 \cdot \dot{m}_{v e n t} \cdot \Delta g-\sum_{j=0}^{4}\left(A w_{j} \cdot B T 11_{j, m}\right)} \\
A 3=\frac{\sum_{j=0}^{4}\left(U_{j} \cdot A W_{j} I_{j}\right)+\left(2501 \cdot \dot{m}_{v e n t} \cdot \Delta g_{h_{3}}\right) \cdot T o+\tau_{g} \cdot I_{j, m} \cdot A g_{j}}{h_{3} \cdot A g_{j}+2501 \cdot \dot{m}_{v e n t} \cdot \Delta g_{h_{3}}+\sum_{j=0}^{4} U W_{j} \cdot A W_{j}}
\end{gathered}
$$

Substituting Equations (26.a) and (27.a) into Equation (11) yields the variation of indoor temperature for a building with roof pond, while using Equations (29.b) and (30) into Equation (10) yields the indoor temperature for a building with the traditional roof.

\section{HEAT TRANSFER COEFFICIENT FOR ROOF POND}

Figure 3 and Equation (11) show the heat balance of roof pond, the left-hand side of the Equation (11) is the change in thermal storage of water. While the first term of the right-hand side is, the heat gains by water due to the incident of solar radiation on the pond. The second term is part of this heat that transferred to the concrete roof bellows the pond, heat lost to the environment by convection and radiation are the third and fourth terms respectively. Finally, the last term is heat lost to the environment due to evaporation of water from the pond.

The upper surface of the water in the pond can be assumed as an upper surface of a hot plate. Thus, the heat transfer coefficient between upper surface layer of pond and ambient air can be calculated as follows [11]. 


$$
\begin{gathered}
\mathrm{Nu}=0.54 \mathrm{Ra}_{\mathrm{Lc}}^{1 / 3} \\
\mathrm{Ra}_{\mathrm{Lc}}=\frac{\text { g. } \beta \cdot\left(\mathrm{T}_{\mathrm{s}}-\mathrm{Tamb}\right) \cdot \mathrm{L}_{\mathrm{c}}^{3}}{\mathrm{v}^{2}} \cdot \mathrm{Pr} \\
\mathrm{Lc}=\frac{\mathrm{A}_{\mathrm{p}}}{\mathrm{P}}
\end{gathered}
$$

Pr is prandtl number, and equals to:

$$
\operatorname{Pr}=\frac{c_{p} \cdot \mu}{k}
$$

The mass convection coefficient can be calculated as follows [12].

$$
\mathrm{Sh}=0.54 .(\mathrm{Gr} \cdot \mathrm{Sc})^{1 / 4}
$$

Where:

Sh is Sherwood number and equals to

$$
\mathrm{Sh}=\frac{\mathrm{h}_{7} \cdot \mathrm{Lc}}{\mathrm{D}_{\mathrm{AB}}}
$$

$\mathrm{D}_{\mathrm{AB}}$ is a diffusion coefficient and calculated as follows [13].

$$
\mathrm{D}_{\mathrm{AB}}=1.87 \times 10^{-10} \frac{\mathrm{T}_{\mathrm{av}}^{2.027}}{\mathrm{~Pa}}
$$

Sc: Schmidt number, and equals to:

$$
\mathrm{Sc}=\frac{v}{\mathrm{D}_{\mathrm{AB}}}
$$

The irradiative heat transfer coefficient can be found using as follows.

$$
\mathrm{h}_{6}=\varepsilon \cdot \sigma \cdot(\mathrm{Tw}+\mathrm{Tamb}) \cdot\left(\mathrm{Tw}^{2}+\mathrm{Tamb}^{2}\right)
$$

The convection heat transfer coefficient between the water layer and concrete roof can be calculated using Equation (30.1) by replacing the thermal properties of air by that for water for $\mathrm{Nu}$, Pr. and Ra numbers.

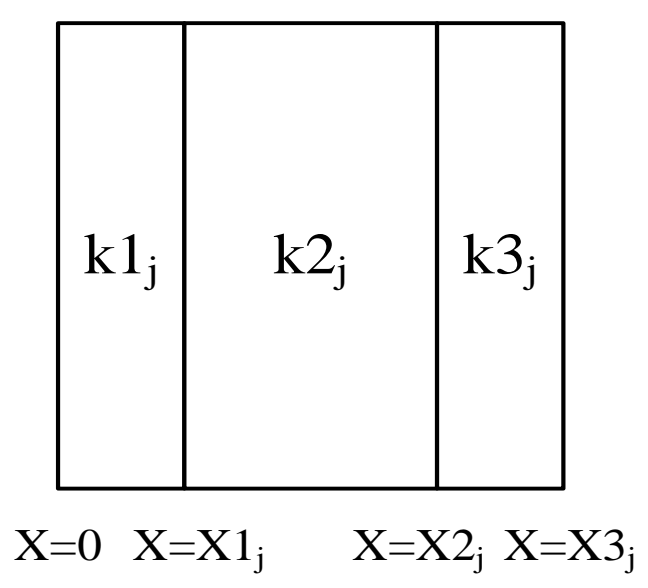

Figure 2. Walls/ roof construction 


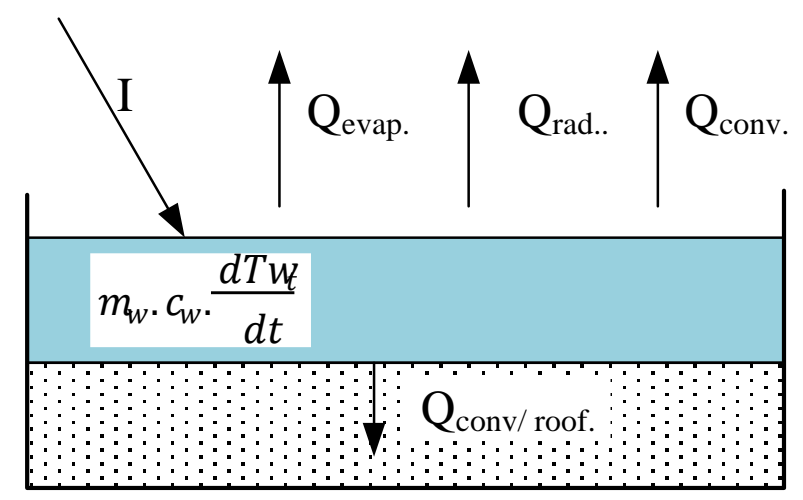

Figure 3. Heat balance of roof the pond

\section{EVAPORATION RATE FROM POND}

The air layer receives water vapor from the upper layer of the pond. Thus, this thin layer of air become saturated and lighter than the upper layer of the air and carrying an amount of water vapor. As this phenomenon is repeated time by the time during the day, a significant mass of water evaporates from the pond. By assuming the water surface is a horizontal heated plate facing upwards, the mass of water evaporated per hour per meter square of pond area, can be calculated from the following formula [14].

\section{EXERGY ANALYSIS OF ROOF POND}

The exergy is defined as the maximum reversible work that can be achieved by a given mass of a working substance, on the condition that, the mass undergoes an entirely reversible process until it reaches the equilibrium state with its environment. From the definition above, it can be said that the exergy is the quality of energy. The general exergy rate equation is [15].

$$
\frac{\mathrm{d} \psi_{\mathrm{t}}}{\mathrm{dt}}=\sum \dot{\mathrm{m}}_{\mathrm{i}} \cdot \psi_{\mathrm{i}}-\sum \dot{\mathrm{m}}_{\mathrm{e} \cdot} \cdot \psi_{\mathrm{e}}+\sum \mathrm{Q} \cdot\left(1-\frac{\mathrm{T}_{\mathrm{o}}}{\mathrm{T}}\right)-\dot{\mathrm{W}}+\mathrm{P}_{\mathrm{o}} \cdot \frac{\mathrm{dV}}{\mathrm{dt}}-\psi_{\text {dest }}
$$

The left-hand term of Equation (34) is the change of the exergy of a control volume with the time. The first and second terms of the right-hand side of the equation are the exergy transfer due to the flow of a given mass. The third is the exergy flow due to heat transfer, the fourth and fifth terms are the exergy transfer due to boundary and shaft works, and finally, the last term is the destruction in exergy due to entropy generation.

Figure 4 shows the exergy flow of the water in the pond. Since the analysis of the pond depends on steady state and there is no work accomplished by the pond, Equation (34) can be reduced to:

$$
\Psi_{\text {dest }}=\dot{\mathrm{m}}_{\mathrm{i}} \cdot \Psi_{\mathrm{i}}+\sum \mathrm{Q} \cdot\left(1-\frac{\mathrm{T}_{\mathrm{o}}}{\mathrm{T}}\right)
$$

The first term of the left-hand side of Equation (35) is the exergy flow to the pond due to makeup water, the second term of the equation is the summation of heat flow to or from the pond, including the exergy flow due to solar radiation, this term is written as:

$$
\sum Q_{\mathrm{t}} \cdot\left(1-\frac{\mathrm{T}_{\mathrm{o}}}{\mathrm{T}}\right)=\psi_{\mathrm{sol}, \mathrm{t}}+\psi_{\text {conv }, \mathrm{t}}+\psi_{\text {rad, } \mathrm{t}}+\psi_{\text {evap }, \mathrm{t}}+\psi_{\text {conv } / \mathrm{R}, \mathrm{t}}
$$

Where, $\psi_{\text {sol,t }}$ is the exergy of the solar radiation on the water of pond [16].

$$
\psi_{\text {sol, }, t=I s_{t} \cdot} \cdot\left[1+\frac{1}{3} \cdot\left(\frac{\mathrm{T}_{\mathrm{o}}}{\mathrm{T}_{\text {sun }}}\right)^{4}-\frac{4}{3}\left(\frac{\mathrm{T}_{\mathrm{o}}}{\mathrm{T}_{\text {sun }}}\right)\right]
$$

$\Psi_{\text {conv,t }}$ is the exergy due to convection heat transfer from the water surface, and equals to: 


$$
\psi_{c o n v, t}=h_{4} \cdot\left(T w_{t}-T a m b_{t}\right) \cdot\left(1-\frac{T_{o}}{T W_{t}}\right)
$$

$\psi_{\text {rad,t }}$ is the exergy due to radiation heat transfer from the water surface

$$
\psi_{\text {rad,t }}=h_{6} \cdot\left(\mathrm{Tw}_{\mathrm{t}}-\mathrm{T}_{\text {sky }_{\mathrm{t}}}\right) \cdot\left(1-\frac{\mathrm{T}_{\text {sky }}}{\mathrm{TW}_{\mathrm{t}}}\right)
$$

$\mathrm{T}_{\text {sky }}$ : sky temperature and can be calculated as follows [17].

$$
\mathrm{T}_{\mathrm{sky}, \mathrm{t}}=\operatorname{Tamb}_{\mathrm{t}} \cdot\left[0.711+0.0056 \cdot \mathrm{T}_{\mathrm{dp}}+0.000073 \mathrm{~T}_{\mathrm{dp}}^{2}+0.013 \cdot \cos (15 . \mathrm{t})\right]^{1 / 4}
$$

Where $\mathrm{T}_{\text {sky,t }}$ and $\mathrm{Tamb}_{\mathrm{t}}$ in Kelvin and the dew point temperature $\mathrm{T}_{\mathrm{dp}}$ in degree Celsius.

$\psi_{\text {evap,t }}$, is the exergy due to evaporation of water, and equals to:

$$
\psi_{\text {evap }, \mathrm{t}}=\dot{\mathrm{m}}_{\text {evap }} \cdot \mathrm{h}_{\mathrm{fg}} \cdot\left(1-\frac{\mathrm{T}_{\mathrm{o}}}{\mathrm{TW}_{\mathrm{t}}}\right)
$$

$\Psi_{\text {conv/R,t }}$ is the heat transfer by convection from the inner surface of the pond.

$$
\psi_{\text {conv/R,t }}=h_{5} \cdot\left(\mathrm{TW}_{\mathrm{t}}-\mathrm{Tr}_{\mathrm{t}}\right) \cdot\left(1-\frac{\mathrm{TW}_{\mathrm{t}}}{\mathrm{Tr}_{\mathrm{t}}}\right)
$$

\section{RESULTS AND DISCUSSION}

Figure 5 shows the variation of solar intensity falls on different wall orientations and roof, in Baghdad, at Aug. 21, 2012. The effect of using roof bond on the swinging of indoor temperature is shown in Figure 6. It can be seen from the figure that, using roof pond instead of traditional roof reduces the mean indoor temperature significantly, but the peak indoor temperature was shifted toward of solar noon by about 2 hours. This shifting may have an adverse effect on the air conditioning unit since it is conjunct with the peak temperature of other walls. The figure also shows that the swinging of outdoor temperature was damped for both traditional roof and roof pond.

The temperature distribution through water in the pond, concrete roof bellows pond, and evaporation rate from the pond are shown in Figure 7. It can be seen that the water in the pond has the minimum temperature, followed by the concrete roof, and finally indoor temperature. The temperature distribution, shown in Figure 7, gives a clear indication that the roof pond acts as heat sink to the heat stored in building, instead of the heat source as in traditional roof. The rate of water evaporated from the pond is a function of the vapor pressure of the moist air above the pond, and in turn, is a function of ambient temperature. That is, the trends of the rate of water

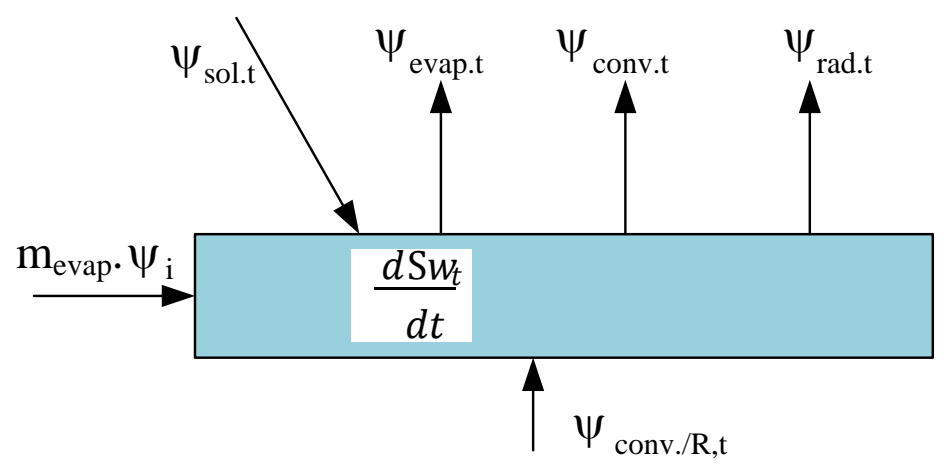

Figure 4. Exergy analysis of the water in the pond 


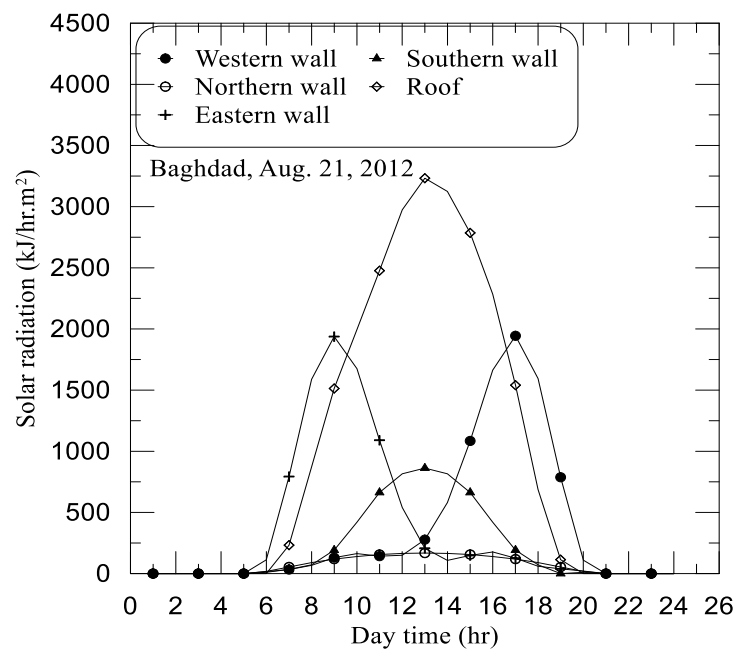

Figure 5. Variation solar intensity on the walls and the roof at Baghdad, Aug. 21, 2012

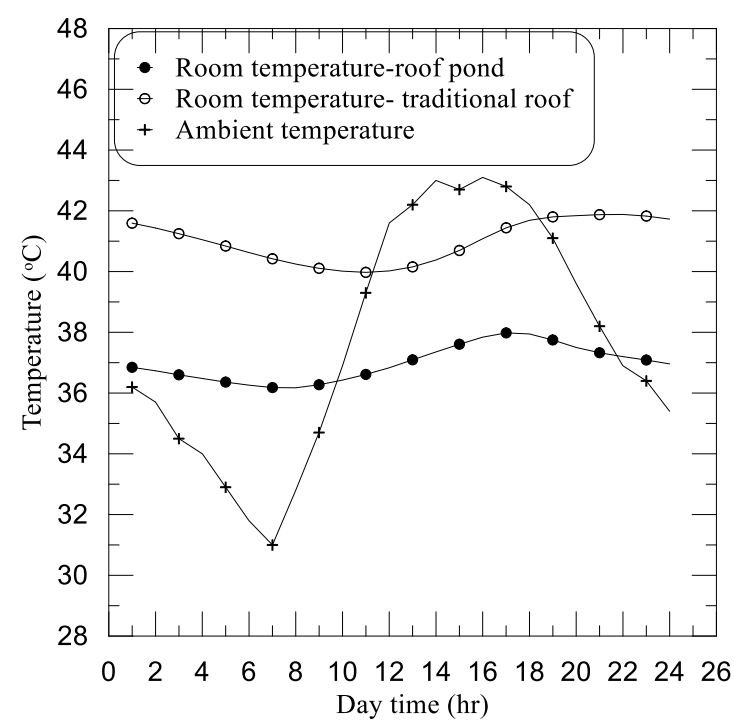

Figure 6. Variation outdoor and indoor temperature with time for the building with a roof pond and a traditional roof

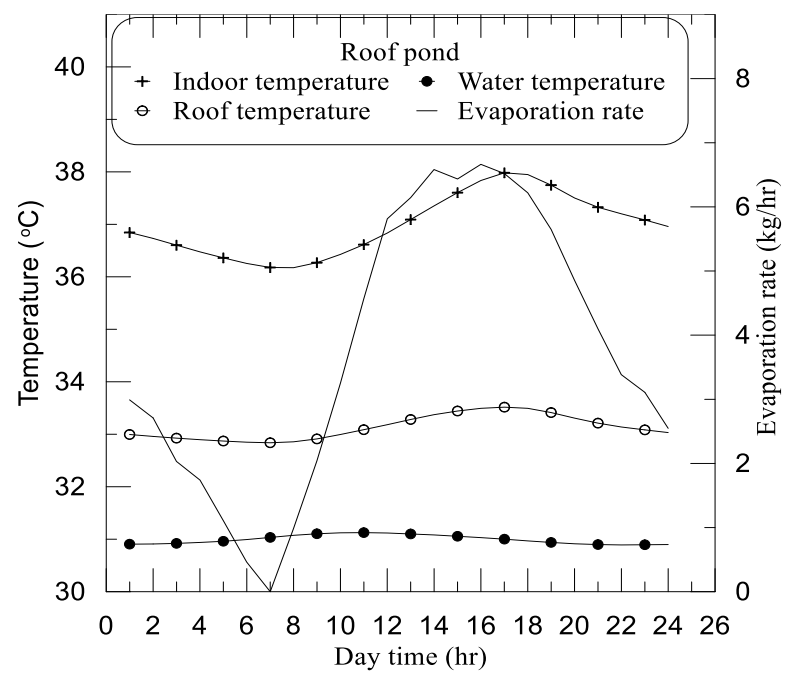

Figure 7. Variation of the indoor, roof, evaporation rate and water temperature with time 


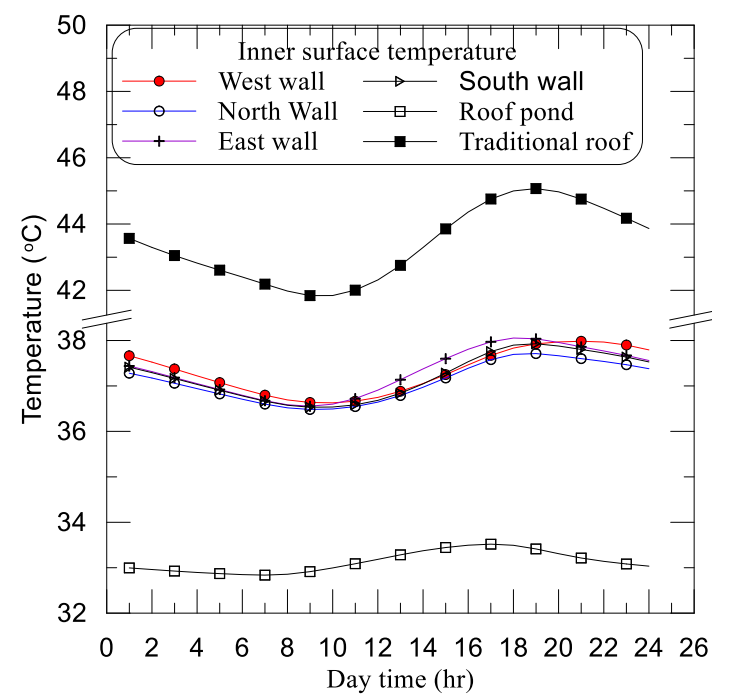

Figure 8. Variation of inside surface temperature of the building components with time.

evaporation follow ambient temperature as shown in Figure 7. Figure 8 shows the inner surface temperature of the building construction, it can be seen that the maximum surface temperature is for the traditional roof, while the roof pond has the minimum surface temperature.

Figure 9 shows the temperature distribution through the traditional roof as well as through the roof pond, at different intervals of time. It can be seen from the figure that the outer surface temperature of the roof pond temperature is stable along the day, and does not follow the swinging of outdoor temperature. While the outer surface temperature of traditional roof effects strongly by the swinging of the outdoor temperature. Also, it can be seen that the indoor temperature is less than inside surface temperature of the traditional and greater than that temperature of the roof pond, the theory of heat sink and source that mentioned in Figure 7 appears clearly in this figure. Figure 10 shows the temperature distribution through Western walls, for both rooms with traditional roof and roof pond. It can be seen from the figure that, using roof pond improved the inside surface temperatures of building walls. The trends of temperature distribution for both walls are the same since the composition of walls are identical.

The rate of heat flow through building structures is shown in Figure 11. The figure shows that traditional roof gives the major part of heat flow to the building while roof pond absorbed heat from building envelope.

The effect of water depth in the pond on the water temperature is shown in Figure 12. Although the water temperature is affected by the water depth, but the effect is insignificant. The figure shows the variation of water temperature due to water depth ranging from $(-0.2)$ to $\left(+0.2{ }^{\circ} \mathrm{C}\right)$. The thickness of concrete roof bellows pond has significant on the inside surface temperature of the roof.

It can be seen from Figure 13 that as the thickness of roof increases, inside surface temperature of roof increases also. These phenomena is due to the increasing of roof thermal mass, which tend to store the absorbed heat from building envelope instead of passes it to the water above the roof. Increasing of inside roof temperature reflects on the rate of heat transfer from building to the water, as shown in Figure 14. It can be seen from the figure

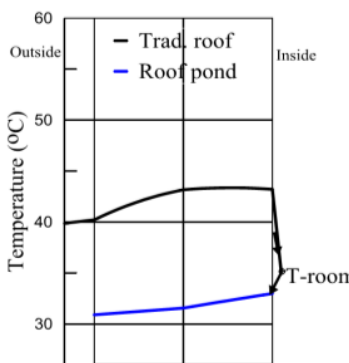

Time $0 \mathrm{hr}$.

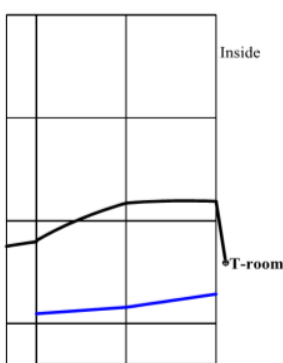

$4 \mathrm{hr}$.

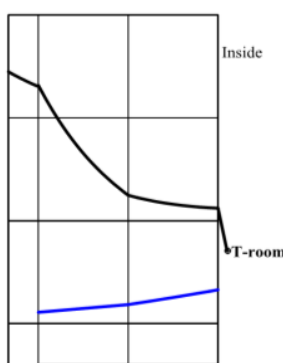

$12 \mathrm{hr}$.

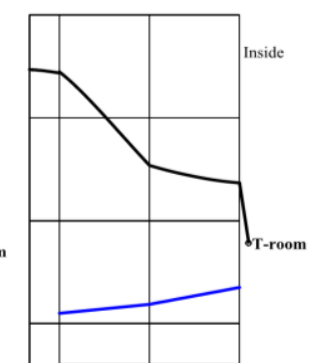

$16 \mathrm{hr}$.

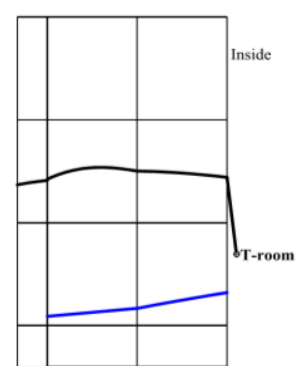

$20 \mathrm{hr}$

Figure 9. Temperature distribution through the traditional roof and the roof pond 


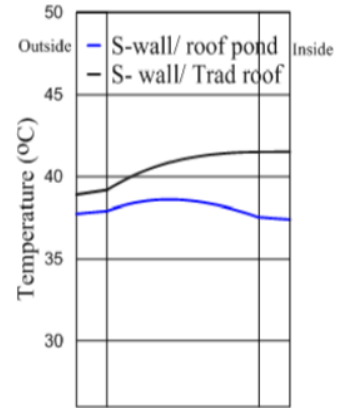

Time $0 \mathrm{hr}$.

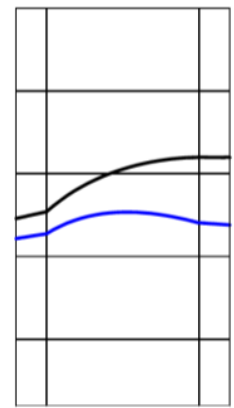

$4 \mathrm{hr}$.

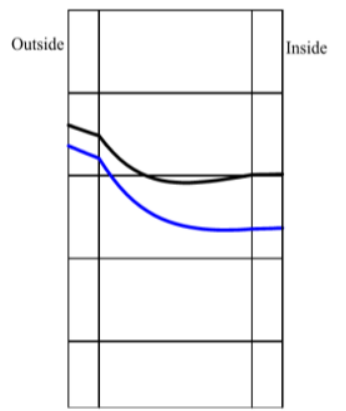

$12 \mathrm{hr}$.

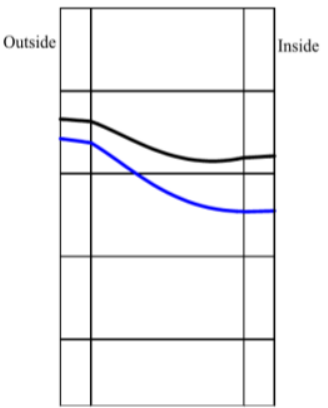

$16 \mathrm{hr}$.

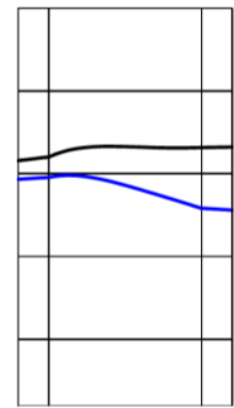

$20 \mathrm{hr}$.

Figure 10. Temperature distribution through the Western wall of building with the roof pond and the traditional

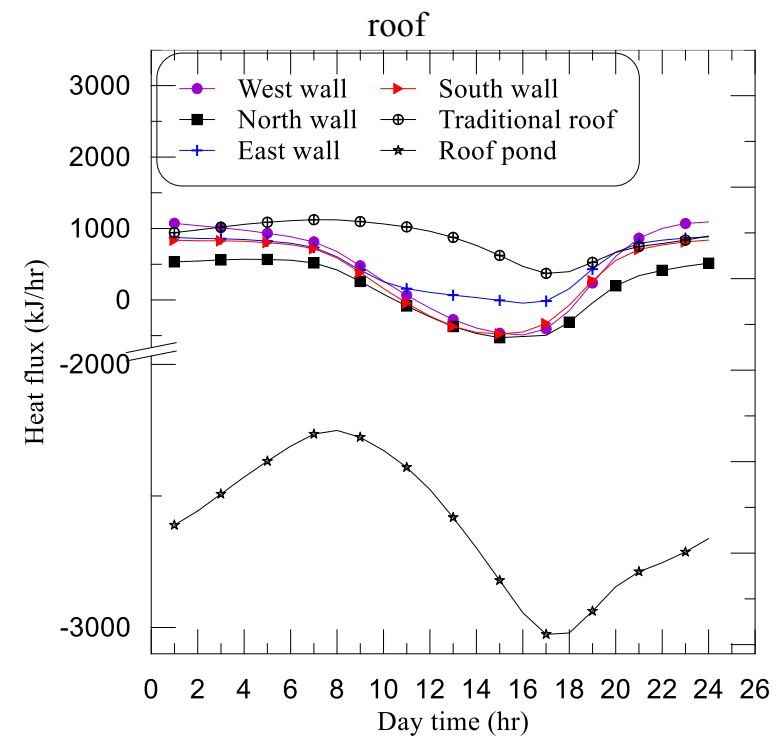

Figure 11. Variation of the rate heat flows to the building structure with the time

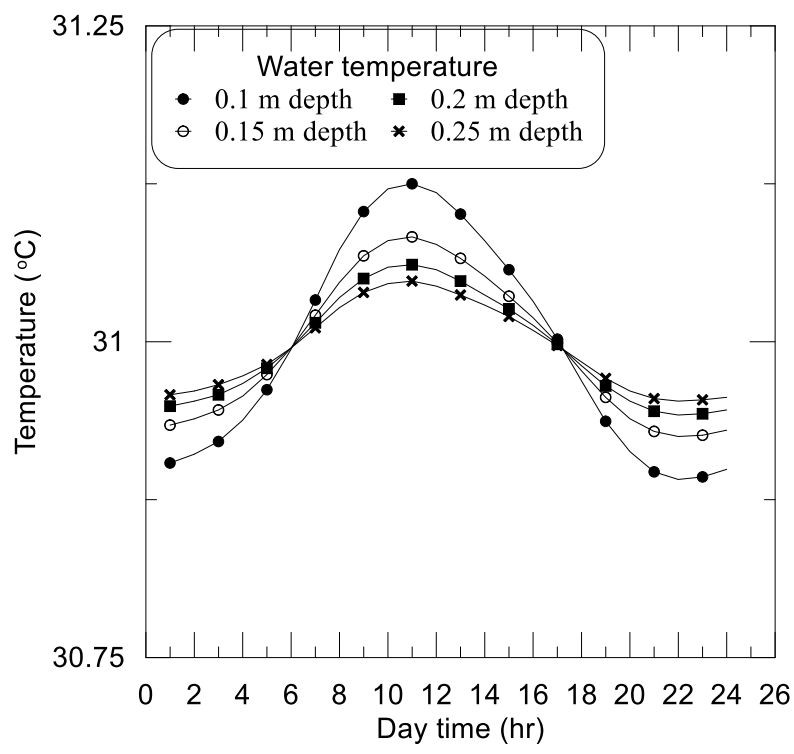

Figure 12. Effect of water depth in the pond on the variation of the water temperature

that when roof thickness increases, less heat is absorbed from the building. The variation of exergy transport due to heat flow by radiation, evaporation convection, and makeup water flow are shown in Figure 15. The figure shows that the maximum exergy flow is due to evaporation of water from the pond, since evaporation 
of water conjunct with a high value of the latent heat of evaporation. The figure shows that the minimum evaporation exergy flow is at 6 a.m. due to reduction in water temperature at that time, as the thermal storage of

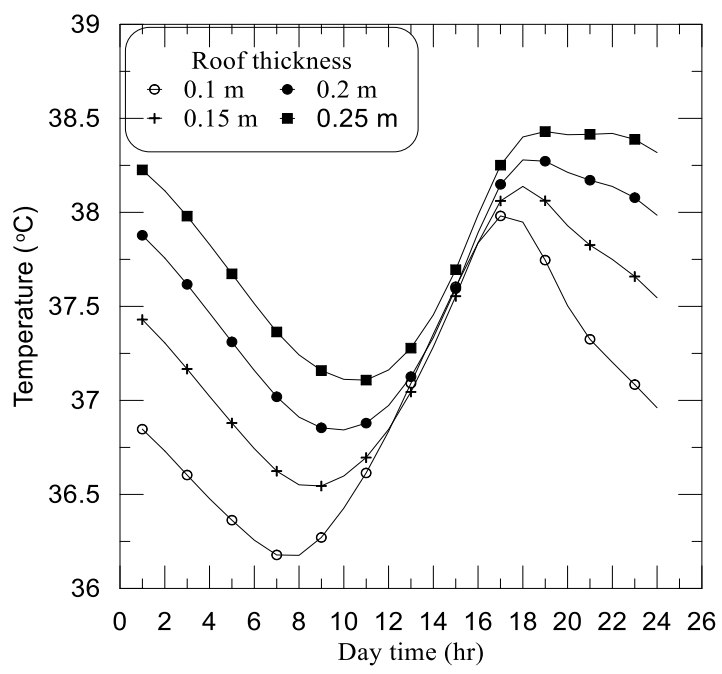

Figure 13. Effect of the concrete layer thickness below the pond on the indoor temperature variation.

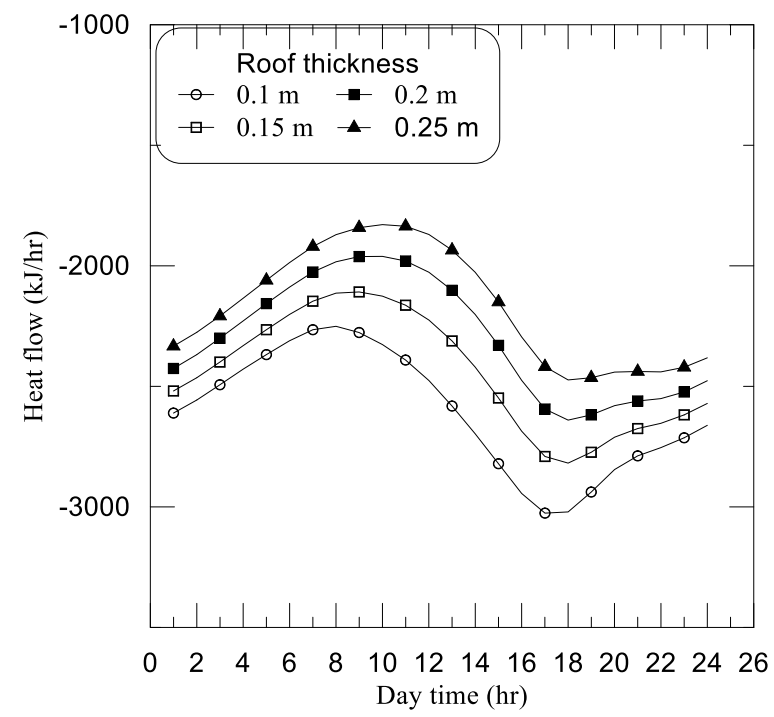

Figure 14. Effect of the thickness of the concrete layer below the pond on the heat flow through the roof pond

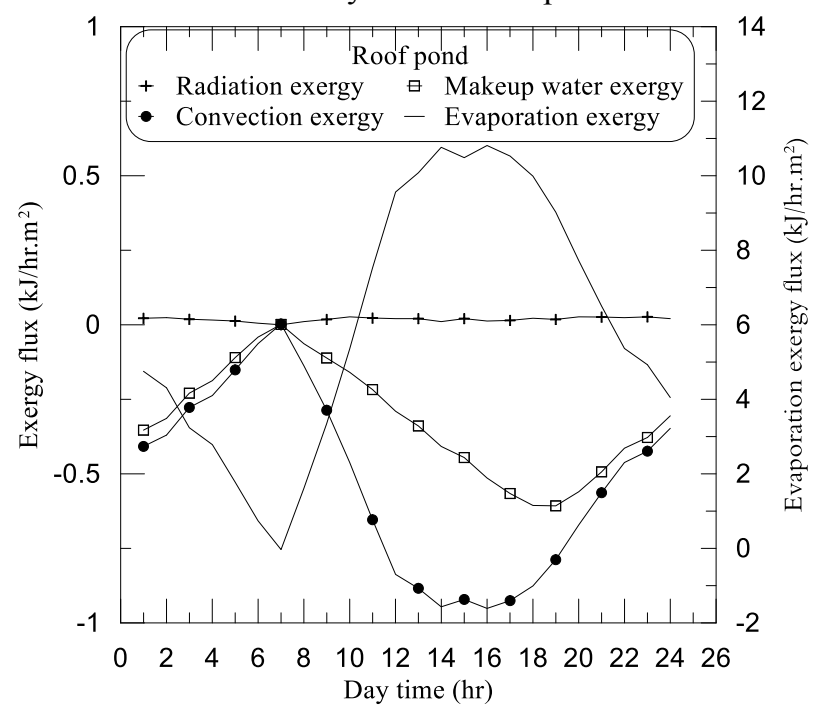

Figure 15. Exergy rate of makeup water, radiation, convection and evaporation heat transfer variation 


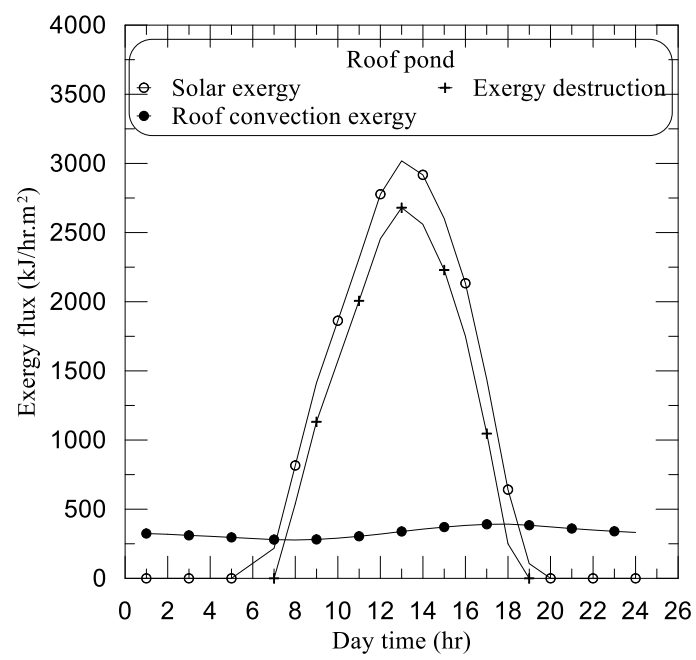

Figure 16. Solar exergy, roof convection exergy and the exergy destruction vs. day time.

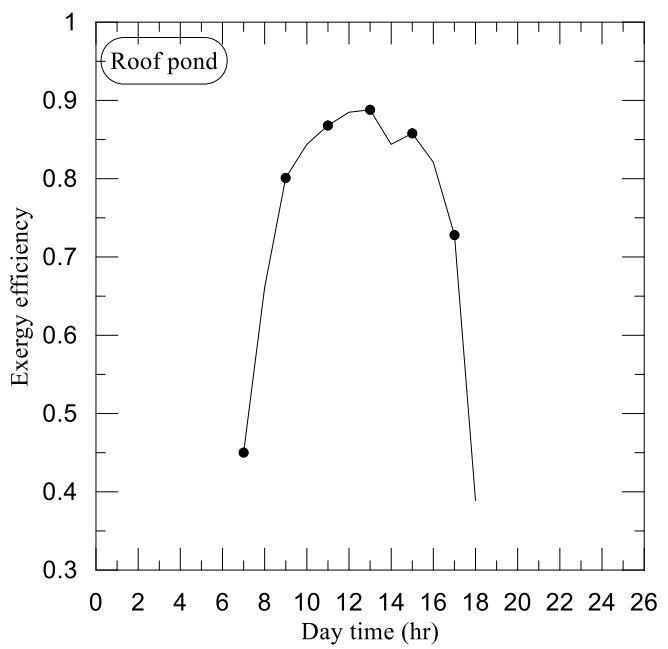

Figure 17. Exergy efficiency of the roof pond vs. time

roof pond reaches maximum at 4 p.m., therefore the exergy flow reaches its maximum value. The exergies flow due other heat flows mentioned above are insignificant.

The exergy flow due to the solar incident on the water in the pond, heat flow through the roof, and exergy destruction are shown in Figure 16. The figure indicates that the maximum exergy flow is due solar radiation. The exergy destruction rate has followed by the intensity of solar radiation. The exergy efficiency of the pond is shown in Figure 17. The maximum destruction in exergy gives the maximum exergy efficiency to the pond. Since the objective of roof pond is to destruct the exergy of solar radiation before entering the building space.

\section{CONCLUSIONS}

Using roof pond in hot, arid zones can reduce the mean indoor temperature in hot summer by about $4^{\circ} \mathrm{C}$. Also, roof pond has damped the effect of outdoor condition on the indoor temperature. Using excessive mass of roof bellows pond has the adverse effect on the building thermal performance. Using roof pond improved inside temperature of building walls. Hence, less heat flows through walls to the building, in addition to, roof pond acts as heat sink to the heat accumulated in building envelope. Maximum exergy flow is due solar radiation, followed by convection heat through the roof, and evaporation heat flow. The maximum exergy destruction through roof pond gives the maximum exergy efficiency to the pond. The mean exergy efficiency of such roof pond is about $64 \%$. 


\section{NOMENCLATURE}

A2 Average value of water temperature, ${ }^{\circ} \mathrm{C}$

A3 Average value of indoor temperature, ${ }^{\circ} \mathrm{C}$

A Area, $\mathrm{m}^{2}$

$\mathrm{B} 2 \mathrm{~m} \quad$ Amplitude of $\mathrm{mth}$ value of water temperature, ${ }^{\circ} \mathrm{C}$

$\mathrm{B} 3 \mathrm{~m} \quad$ Amplitude of $\mathrm{mth}$ value indoor temperature, ${ }^{\circ} \mathrm{C}$

$\mathrm{c}_{\mathrm{a}} \quad$ Specific heat of air, $\mathrm{kJ} / \mathrm{kg} \mathrm{K}$

$\mathrm{cn}_{\mathrm{j}} \quad$ Specific heat of $\mathrm{n}$ layer in $\mathrm{j}$ wall of the wall/roof material, $\mathrm{kJ} / \mathrm{kg} \mathrm{K}$

$c_{p} \quad$ Specific heat of air, $\mathrm{kJ} / \mathrm{kg} \mathrm{K}$

$\mathrm{c}_{\mathrm{R}} \quad$ Specific heat of roof material, $\mathrm{kJ} / \mathrm{kg} \mathrm{K}$

$\mathrm{CW} \quad$ Specific heat of water, $\mathrm{kJ} / \mathrm{kg} \mathrm{K}$

$\mathrm{D}_{\mathrm{AB}} \quad$ Diffusion coefficient, $\mathrm{m}^{2} / \mathrm{s}$

g Acceleration due gravity $\mathrm{m} / \mathrm{s}^{2}$

$\mathrm{h}_{1} \quad$ Coefficient of heat transfer by long-wave radiation and convection at the outer surface, $\mathrm{kJ} / \mathrm{hr} . \mathrm{m}^{2}$. $\mathrm{K}$

$\mathrm{h}_{2} \quad$ Coefficient of heat transfer by long-wave radiation and convection at the inner surface, $\mathrm{kJ} / \mathrm{hr} . \mathrm{m}^{2} . \mathrm{K}$

$\mathrm{h}_{3} \quad$ Convective and radiative heat transfer coefficient of the glass, $\mathrm{kJ} / \mathrm{hr} . \mathrm{m}^{2} . \mathrm{K}$

$\mathrm{h}_{4} \quad$ Heat transfer coefficient between water and outer surface of the roof, $\mathrm{kJ} / \mathrm{hr} . \mathrm{m}^{2} . \mathrm{K}$

$\mathrm{h}_{5} \quad$ Convective heat transfer coefficient between the water surface and the ambient temperature $\mathrm{kJ} / \mathrm{hr}$. $\mathrm{m}^{2} . \mathrm{K}$

$\mathrm{h}_{6} \quad$ Radiative heat transfer coefficient between the water surface and the ambient temperature, $\mathrm{kJ} / \mathrm{hr}$. $\mathrm{m}^{2} . \mathrm{K}$

$\mathrm{h}_{7} \quad$ Mass convection coefficient, $\mathrm{m} / \mathrm{s}$

$\mathrm{h}_{\mathrm{fg}} \quad$ Latent heat of evaporation of water, $\mathrm{kJ} / \mathrm{kg}$

$\mathrm{I}_{\mathrm{j}, \mathrm{t}} \quad$ Solar radiation incidents on $\mathrm{j}$-wall, $\mathrm{kJ} / \mathrm{hr} \mathrm{m}^{2}$

$\mathrm{I}_{\mathrm{j}, \mathrm{m}} \quad$ Amplitude of mth value of solar intensity, $\mathrm{kJ} / \mathrm{hr} \mathrm{m}^{2}$

$\mathrm{I}_{\mathrm{j}, \mathrm{t}} \quad$ Average value of solar intensity on $\mathrm{jth}$ wall, $\mathrm{kJ} / \mathrm{hr} \mathrm{m}^{2}$

$\mathrm{IS}_{\mathrm{j}, \mathrm{t}} \quad$ Solar intensity on $\mathrm{jth}$ wall, $\mathrm{kJ} / \mathrm{hr} \mathrm{m}^{2}$

$\mathrm{kn}_{\mathrm{j}} \quad$ Thermal conductivity of $\mathrm{n}$ layer in $\mathrm{j}$ wall of the wall/roof material $\mathrm{kJ} / \mathrm{hr} . \mathrm{m} . \mathrm{K}$

$\mathrm{k}_{\mathrm{R}} \quad$ Thermal conductivity of roof material, $\mathrm{kJ} / \mathrm{hr}$. m. K

Lc Characteristic length of the surface area of the pond, $m$

$\mathrm{m} \quad$ Number of harmonic, for this work the value of $\mathrm{m}$ is 1 to 6 .

$\dot{\mathrm{m}} \quad$ Mass flow rate, $\mathrm{kg} / \mathrm{s}$

$\mathrm{Nu} \quad$ Nussult number

$\mathrm{P} \quad$ Pond perimeter, $\mathrm{m}$

$\mathrm{Pa} \quad$ atmospheric pressure (atm.)

$\mathrm{P}_{\mathrm{o}} \quad$ Dead state pressure, $\mathrm{kPa}$

Pr Prandtl number

$\mathrm{p}_{\mathrm{v}} \quad$ Water vapour pressure in the atmospheric, $\mathrm{kPa}$

Q Heat transfer to or from the control volume, $\mathrm{kJ} / \mathrm{hr}$

Ra Rayleigh number

Qroof $_{\mathrm{t}}$ Heat flow through roof pond, $\mathrm{kJ} / \mathrm{hr}$.

Sc Schmidt number

Sh Sherwood number

$\mathrm{Tamb}_{\mathrm{t}} \quad$ Ambient temperature, ${ }^{\circ} \mathrm{C}$

$\mathrm{Tin}_{\mathrm{t}} \quad$ Indoor temperature, ${ }^{\circ} \mathrm{C}$

$\mathrm{T}_{\mathrm{m}} \quad$ Amplitude of $\mathrm{nth}$ value of ambient temperature, ${ }^{\circ} \mathrm{C}$

$\mathrm{T}_{\mathrm{o}} \quad$ Dead state temperature, $\mathrm{K}$

$\mathrm{T}_{\mathrm{s}} \quad$ Water surface temperature, ${ }^{\circ} \mathrm{C}$

$\mathrm{Ts}_{\mathrm{j}, \mathrm{t}} \quad$ Sol-air temperature to $\mathrm{jth}$ wall, ${ }^{\circ} \mathrm{C}$ 
$\mathrm{Ts}_{\mathrm{j}} \quad$ Average value of sol-air temperature to $\mathrm{jth}$ wall, ${ }^{\circ} \mathrm{C}$

$\mathrm{Ts}_{\mathrm{j}, \mathrm{m}} \quad$ Amplitude of $\mathrm{mth}$ value of sol-air temperature, ${ }^{\circ} \mathrm{C}$

$\mathrm{T}_{\text {sun }} \quad$ The sun temperature, $\mathrm{K}$

$\mathrm{TW}_{\mathrm{j}, \mathrm{t}} \quad$ Temperature distribution through $1 \mathrm{st}$ layer of $\mathrm{jth}$ wall, ${ }^{\circ} \mathrm{C}$

$\mathrm{TW}_{\mathrm{j}, \mathrm{t}} \quad$ Temperature distribution through 2 nd layer of $\mathrm{jth}$ wall, ${ }^{\circ} \mathrm{C}$

$\mathrm{TW}_{\mathrm{j}, \mathrm{t}} \quad$ Temperature distribution through third layer of $\mathrm{jth}$ wall, ${ }^{\circ} \mathrm{C}$

$\mathrm{Tw}_{\mathrm{t}} \quad$ Water temperature, ${ }^{\circ} \mathrm{C}, \mathrm{K}$.

$\mathrm{V} \quad$ Volume, $\mathrm{m}^{3}$

$\dot{\mathrm{W}} \quad$ Boundary work, $\mathrm{kJ} / \mathrm{hr}$

\section{Subscript}

$\begin{array}{ll}\mathrm{i} & \text { Inlet } \\ \mathrm{e} & \text { Exit } \\ \text { vent. } & \text { Ventilation } \\ \text { conv. } & \text { Convection } \\ \text { rad. } & \text { Radiation } \\ \text { evap. } & \text { Evaporation } \\ \text { conv/R } & \text { convection heat through the roof } \\ \text { av } & \text { Average } \\ \mathrm{dp} & \text { dew point } \\ \text { sol } & \text { Sol-air } \\ \text { sky } & \text { Sky } \\ \mathrm{j} & \text { number of the surface, walls and roof. } \mathrm{j}=0 \text { for Western wall, } \mathrm{j}=1 \text { for Northern wall, } \mathrm{j}=2 \text { for Eastern } \\ \mathrm{p} & \text { wall, } \mathrm{j}=3 \text { for Southern wall and } \mathrm{j}=4 \text { for roof } \\ \mathrm{R} & \text { Pond } \\ \mathrm{g} & \text { Roof } \\ \mathrm{dest} & \text { Glass }\end{array}$

\section{Greek symbols}

$\alpha_{j} \quad$ Absorptivity of $\mathrm{j}$-surface for solar radiation

$\varepsilon_{\mathrm{j}} \quad$ Hemispherical emittance of $\mathrm{j}$ - surface

$\rho_{R} \quad$ Density of roof material, $(\mathrm{kg} / \mathrm{m} 3$

$\rho n_{j} \quad$ Density of $n$ layer in $\mathrm{j}$ wall of the wall $/$ roof material, $\mathrm{kg} / \mathrm{m} 3$

$\rho_{\text {sat }} \quad$ Density of water vapour at water temperature, $\mathrm{kg} / \mathrm{m} 3$

$\rho_{\mathrm{v}} \quad$ Density of water vapour at ambient temperature, $\mathrm{kg} / \mathrm{m} 3$

$\tau_{\mathrm{g}} \quad$ Transmittance of glass to solar radiation

$\tau_{w} \quad$ Transmittance of water to solar radiation

$\psi \quad$ Exergy, $\mathrm{kJ} / \mathrm{kg}$

$\varepsilon \quad$ Emissivity of water

$\emptyset \quad$ Relative humidity

$\Delta \mathrm{R}_{\mathrm{j}} \quad$ Difference between long-wave radiation incident on $\mathrm{j}$-surface from sky and surroundings and radiation emitted by the blackbody at outdoor air temperature, $\mathrm{kJ} / \mathrm{hr} . \mathrm{m} 2$

$\Delta \mathrm{g} \quad$ Difference between moisture content of the indoor and outdoor air $(\mathrm{kgw} / \mathrm{kga})$

$\mu \quad$ Dynamic viscosity, N.s/m2

$\beta \quad$ Volume expansion coefficient, $1 / \mathrm{K}$

$\sigma \quad$ Stefan-Boltzmann constant equals, $\mathrm{W} / \mathrm{m} 2 \cdot \mathrm{K} 4$

u Kinematic viscosity, $\mathrm{m} 2 / \mathrm{s}$ 


\section{REFERENCES}

[1] Sodha, M.S., Kumar, A., Singh, U., Tiwari, G.N., 1980a. Periodic theory of an open roof pond. Appl. Energy 7, 305-319.

[2] Sodha, M.S., Srivastava, A., Kumar, A., Tiwari, G.N., 1980b. Heating and cooling buildings by flow of water over the roof. Appl. Energy 7, 229-242.

[3] Srivastava, A., Tiwari, G.N., 1984. Experimental validation of a thermal model of an evaporative cooling system. Energy Convers. Manag. 24, 305-311.

[4] Tang, R., Etzion, Y., 2004. On thermal performance of an improved roof pond for cooling buildings. Build. Environ. 39, 201-209.

[5] Kharrufa, S.N., Adil, Y., 2008. Roof pond cooling of buildings in hot arid climates. Build. Environ. 43, 82-89. [6] Sabzi, D., Haseli, P., Jafarian, M., Karimi, G., Taheri, M., 2015. Investigation of cooling load reduction in buildings by passive cooling options applied on roof. Energy Build. 109, 135-142.

[7] Hamdan, M.A., Al-Qudah, L.A., 2016. Performance Improvement of Shallow Solar Pond Using Nanoparticles. Int J Therm. Environ. Eng. 11, 0-0.

[8] Anand Y, Anand S, Gupta A, Tyagi S. Building envelope performance with different insulating materials-An exergy approach. Journal of Thermal Engineering. 2015;1(4):433-9.

[9] Beerends, R.J., 2003. Fourier and Laplace Transforms. Cambridge University Press.

[10] ASHRAE, 2013 handbook of fundamentals .

[11] Cengel, Y.A., 2007. Heat and mass transfer: a practical approach. McGraw-Hill, New York.

[12]Yunus, C.A., Afshin, J.G., 2011. Heat and Mass Transfer: Fundamentals and Applications. Tata McGraw-Hill, New Delhi, India.

[13] Marrero, T.R., Mason, E.A., 1972. Gaseous Diffusion Coefficients. J. Phys. Chem. Ref. Data 1, 3-118. doi: $10.1063 / 1.3253094$

[14] Harbeck, G.E., 1958. Water-loss Investigations: Lake Mead Studies. U.S. Government Printing Office.

[15] Borgnakke, C., Sonntag, R.E., 2016. Fundamentals of thermodynamics. Wiley Global Education.

[16] Ranjan, K.R., Kaushik, S.C., 2013. Energy, exergy and thermo-economic analysis of solar distillation systems: A review. Renew. Sustain. Energy Rev. 27, 709-723.

[17] Duffie, J.A., Beckman, W.A., 2013. Solar Engineering of Thermal Processes. John Wiley \& Sons.

\section{APPENDIX 1}

constants for temperature distribution through roof pond

Constants of roof pond

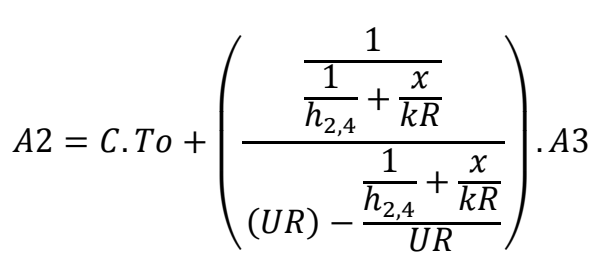

$$
\begin{aligned}
& A 1=\frac{A 3-A 2-\frac{\tau_{w}}{h_{5}} \cdot I_{4}}{h_{5} \cdot k R} \\
& R 0_{m}=\frac{1+\frac{h_{4}}{k R \cdot \beta_{m}}}{1-\frac{h_{4}}{k R \cdot \beta_{m}}} \\
& F 0_{m}=\frac{\frac{h_{4}}{k R \cdot \beta_{m}}}{1-\frac{h_{4}}{k R \cdot \beta_{m}}} \\
& R 1_{m}=\frac{1-\frac{h_{2}}{k R \cdot \beta_{m}}}{1+\frac{h_{4}}{k R \cdot \beta_{m}}} \cdot e^{-2 \cdot \beta_{m} \cdot x} \\
& C=\frac{\left(\tau_{w}-\alpha \cdot \frac{\frac{1}{h_{2,4}}+\frac{x}{k R}}{U R}\right) \cdot I_{4}+\left(h_{5}+h_{6}+\emptyset . . p_{v} h_{7}\right)}{\left(h_{4}+h_{5}+h_{6}+p_{v} \cdot h_{7}\right)-\frac{\frac{1}{h_{2,4}}+\frac{x}{k R}}{U R} \cdot h_{4}} \\
& B 2=\frac{\frac{A 3}{h_{1}}+A 1 \cdot\left(\frac{1}{h_{2,4}}+\frac{x}{k R}\right)+\frac{\tau_{w}}{h_{5}} \cdot\left(\frac{1}{h_{2,4}}+\frac{x}{k R}\right) \cdot I_{4}}{\frac{1}{h_{4}}+\frac{1}{h_{2,4}}+\frac{x}{k R}} \\
& F 1_{m}=\frac{\frac{h_{2}}{k R \cdot \beta_{m}}}{1+\frac{h_{4}}{k R \cdot \beta_{m}}} \cdot e^{-\cdot \beta_{m} \cdot x}
\end{aligned}
$$




$$
\begin{aligned}
& R 2_{m}=\frac{F 0_{m}}{R 0_{m}-R 1_{m}} \\
& F 2_{m}=\frac{F 1_{m}}{R 0_{m}-R 1_{m}} \\
& R 3_{m}=R 1_{m} \cdot R 2_{m} \\
& F 3_{m}=R 1_{m} \cdot F 2_{m}+F 1_{m} \\
& R 4_{m}=\frac{m_{w} c_{w} \cdot i \cdot m \cdot \omega}{A R}+\left(h_{4}+h_{5}+h_{6}+p_{v} \cdot h_{7}\right) \quad F 4_{m}=h_{4} \cdot\left(F 2_{m}+F 3_{m}\right) \\
& R 5_{m}=\frac{\left(h_{4}+h_{5}+h_{6}+p_{v} \cdot h_{7}\right) \cdot R 3_{m}}{R 4_{m}} \quad F 5_{m}=\frac{R 3_{m} \cdot F 4_{m}}{R 4_{m}} \\
& R 6_{m}=\frac{\left(h_{4}+h_{5}+h_{6}+p_{v} \cdot h_{7}\right) \cdot R 2_{m}}{R 4_{m}} \quad F 6_{m}=\frac{R 2_{m} \cdot F 4_{m}}{R 4_{m}}+F 2_{m} \\
& R 7_{m}=h_{4 \cdot}\left(R 5_{m} \cdot e^{\cdot \beta_{m} \cdot x}+R 6_{m} \cdot e^{-\beta_{m} \cdot x}\right) \\
& \mathrm{N} 0_{\mathrm{m}}=\frac{\frac{\tau_{\mathrm{w}}}{\mathrm{kR} \cdot \beta_{\mathrm{m}}}}{1-\frac{\mathrm{h}_{4}}{\mathrm{kR} \cdot \beta_{\mathrm{m}}}} \\
& F 7_{m}=h_{4 \cdot} \cdot\left(F 5_{m} \cdot e^{\cdot \beta_{m} \cdot x}+F 6_{m} \cdot e^{-\beta_{m} \cdot x}-1\right) \\
& \mathrm{N} 1_{\mathrm{m}}=\frac{\mathrm{N} 0_{\mathrm{m}}}{\mathrm{R} 0_{\mathrm{m}}-\mathrm{R} 1_{\mathrm{m}}} \\
& \mathrm{B} 2_{\mathrm{m}}=\mathrm{N} 4_{\mathrm{m}} \cdot \mathrm{I}_{4, \mathrm{~m}}+\mathrm{F} 5_{\mathrm{m}} \cdot \mathrm{B} 3_{\mathrm{m}}+\mathrm{R} 5_{\mathrm{m}} \cdot \mathrm{T}_{\mathrm{m}} \\
& \mathrm{N} 2_{\mathrm{m}}=\mathrm{R} 1_{\mathrm{m}} \cdot \mathrm{N} 1_{\mathrm{m}} \\
& \mathrm{B} 3_{\mathrm{m}}=\frac{\mathrm{N} 3_{\mathrm{m}}}{\mathrm{R} 4_{\mathrm{m}}} \cdot \mathrm{I}_{4, \mathrm{~m}}+\frac{\mathrm{F} 4_{\mathrm{m}}}{\mathrm{R} 4_{\mathrm{m}}} \cdot \mathrm{B} 3_{\mathrm{m}} \\
& +\frac{\left(h_{4}+h_{5}+h_{6}+p_{v} \cdot h_{7}\right)}{R 4_{m}} \cdot T_{m} \\
& E 1_{j}=U W_{j}\left[\left(\frac{x 1_{j}}{k 1_{j}}+\frac{1}{h 1}+\frac{x 2_{j}-x 1_{j}}{k 2_{j}}+\frac{x 3_{j}-x 2_{j}}{k 3_{j}}\right) \cdot T s_{j}\right. \\
& \left.+\frac{\mathrm{A} 3}{\mathrm{~h} 2} \mathrm{j}_{\mathrm{j}}\right] \\
& \mathrm{N} 4_{\mathrm{m}}=\frac{\mathrm{R} 3_{\mathrm{m}} \cdot \mathrm{N} 3_{\mathrm{m}}}{\mathrm{R} 4_{\mathrm{m}}}+\mathrm{N} 2_{\mathrm{m}} \\
& \mathrm{P} 1_{\mathrm{j}}=\frac{\mathrm{UW}_{\mathrm{j}}}{\mathrm{k} 1_{\mathrm{j}}} \cdot\left(\mathrm{A} 3-\mathrm{Ts}_{\mathrm{j}}\right)
\end{aligned}
$$

\section{APPENDIX 2}

Constants for temperature distribution through triple layered walls/Roof

$$
\begin{aligned}
& \mathrm{BTO}_{\mathrm{j}, \mathrm{m}}=\frac{1-\frac{\mathrm{h} 2_{\mathrm{j}}}{\mathrm{k} 3_{\mathrm{j}} \gamma 3_{\mathrm{j}, \mathrm{m}}}}{1+\frac{\mathrm{h} 2_{\mathrm{j}}}{\mathrm{k} 3_{\mathrm{j}} \gamma 3_{\mathrm{j}, \mathrm{m}}}} \cdot \mathrm{e}^{-2 \cdot \gamma 3_{\mathrm{j}, \mathrm{m} \cdot \mathrm{x} 3_{\mathrm{j}}}} \\
& \mathrm{CT}_{j, \mathrm{~m}}=\frac{\frac{\mathrm{h} 2_{\mathrm{j}}}{\mathrm{k} 3_{\mathrm{j}} \gamma 3_{\mathrm{j}, \mathrm{m}}}}{1+\frac{\mathrm{h} 2_{\mathrm{j}}}{\mathrm{k} 3_{\mathrm{j}} \gamma 3_{\mathrm{j}, \mathrm{m}}}} \cdot \mathrm{e}^{-\gamma 3_{\mathrm{j}, \mathrm{m}} \times \mathrm{x} 3_{\mathrm{j}}} \\
& B T 1_{j, m}=B T 0_{j, m} \cdot e^{\gamma 3_{j, m} \times x 2_{j}}+e^{-\gamma 3_{j, m} \cdot x 2_{j}} \\
& \mathrm{CT} 1_{j, m}=B T 0_{j, m} \cdot e^{\gamma 3_{j, m} \cdot \mathrm{x} 2_{j}} \\
& \mathrm{BT} 2_{\mathrm{j}, \mathrm{m}}=\frac{\mathrm{k} 3_{\mathrm{j}} \cdot \gamma 3_{\mathrm{j}, \mathrm{m}}}{\mathrm{k} 2_{\mathrm{j}} \cdot \gamma 2_{\mathrm{j}, \mathrm{m}}}\left(\mathrm{BT}_{\mathrm{j}, \mathrm{m}} \cdot \mathrm{e}^{\gamma 3_{\mathrm{j}, \mathrm{m}} \cdot \mathrm{x} 2_{\mathrm{j}}}-\mathrm{e}^{-\gamma 3_{\mathrm{j}, \mathrm{m}} \cdot \mathrm{x} 2_{\mathrm{j}}}\right) \\
& \mathrm{CT} 2_{\mathrm{j}, \mathrm{m}}=\frac{\mathrm{k} 3_{\mathrm{j}} \cdot \gamma 3_{\mathrm{j}, \mathrm{m}}}{\mathrm{k} 2_{\mathrm{j} \cdot} \cdot \gamma 2_{\mathrm{j}, \mathrm{m}}} \cdot \mathrm{CT} 0_{\mathrm{j}, \mathrm{m}} \cdot \mathrm{e}^{\gamma 3_{\mathrm{j}, \mathrm{m}} \cdot \mathrm{x} 2_{\mathrm{j}}}
\end{aligned}
$$




$$
\begin{aligned}
& B T 3_{j, m}=\frac{1}{2} \cdot\left(B T 1_{j, m}+B T 2_{j, m}\right) \cdot e^{-\gamma 2_{j, m} \times 2_{j}} \\
& B T 4_{j, m}=\frac{1}{2} \cdot\left(B T 1_{j, m}-B T 2_{j, m}\right) \cdot e^{\gamma 2_{j, m} \cdot x 2_{j}} \\
& \mathrm{CT} 3_{\mathrm{j}, \mathrm{m}}=\frac{1}{2} \cdot\left(\mathrm{CT} 1_{\mathrm{j}, \mathrm{m}}+\mathrm{CT} 2_{\mathrm{j}, \mathrm{m}}\right) \cdot \mathrm{e}^{-\gamma 2_{\mathrm{j}, \mathrm{m}} \times \mathrm{x} 2_{\mathrm{j}}} \\
& \mathrm{CT} 4_{\mathrm{j}, \mathrm{m}}=\frac{1}{2} \cdot\left(\mathrm{CT} 1_{\mathrm{j}, \mathrm{m}}-\mathrm{CT} 2_{\mathrm{j}, \mathrm{m}}\right) \cdot \mathrm{e}^{\gamma 2_{\mathrm{j}, \mathrm{m}} \times 2_{\mathrm{j}}} \\
& B T 5_{j, m}=B T 3_{j, m} \cdot e^{\gamma 2_{j, m} \cdot x 1_{j}}+B T 4_{j, m} \cdot e^{-\gamma 2_{j, m} \cdot x 1_{j}} \\
& \mathrm{CT} 5_{\mathrm{j}, \mathrm{m}}=\mathrm{CT} 3_{\mathrm{j}, \mathrm{m} .} \mathrm{e}^{\gamma 2_{\mathrm{j}, \mathrm{m}} \times \mathrm{x} 1_{\mathrm{j}}}+\mathrm{CT} 4_{\mathrm{j}, \mathrm{m} .} \mathrm{e}^{-\gamma 2_{\mathrm{j}, \mathrm{m}} \times 1_{\mathrm{j}}} \\
& \mathrm{BT}_{\mathrm{j}, \mathrm{m}}=\frac{\mathrm{k} 2_{\mathrm{j}} \cdot \gamma 2_{\mathrm{j}, \mathrm{m}}}{\mathrm{k} 1_{\mathrm{j}} \cdot \gamma 1_{\mathrm{j}, \mathrm{m}}}\left(\mathrm{BT}_{\mathrm{j}, \mathrm{m}} \cdot \mathrm{e}^{\gamma 3_{\mathrm{j}, \mathrm{m} \cdot \mathrm{x}} \times 1_{\mathrm{j}}}\right. \\
& \text { - BT4. } \mathrm{e}^{-\gamma 3_{\mathrm{j}, \mathrm{m}} \cdot \mathrm{x} 1_{\mathrm{j}}} \\
& \mathrm{CT}_{\mathrm{j}, \mathrm{m}}=\frac{\mathrm{k} 2_{\mathrm{j}} \cdot \gamma 2_{\mathrm{j}, \mathrm{m}}}{\mathrm{k} 1_{\mathrm{j} \cdot} \cdot \gamma 1_{\mathrm{j}, \mathrm{m}}}\left(\mathrm{CT} 3_{\mathrm{j}, \mathrm{m}} \cdot \mathrm{e}^{\gamma 3_{\mathrm{j}, \mathrm{m}} \cdot \mathrm{x} 1_{\mathrm{j}}}\right. \\
& \text { - CT4. } e^{-\gamma 3_{j, m} \cdot \mathrm{x} 1_{j}} \\
& B T 7_{j, m}=\frac{1}{2} \cdot\left(B T 5_{j, m}+B T 6_{j, m}\right) \cdot e^{-\gamma 1_{j, m} \cdot x 2_{j}} \\
& \mathrm{CT}_{\mathrm{j}, \mathrm{m}}=\frac{1}{2} \cdot\left(\mathrm{CT} 5_{\mathrm{j}, \mathrm{m}}+\mathrm{CT} 6_{\mathrm{j}, \mathrm{m}}\right) \cdot \mathrm{e}^{-\gamma 1_{\mathrm{j}, \mathrm{m}} \times 2_{\mathrm{j}}} \\
& B T 8_{j, m}=\frac{1}{2} \cdot\left(B T 5_{j, m}-B T 6_{j, m}\right) \cdot e^{\gamma 1_{j, m} \cdot x 2_{j}} \\
& \mathrm{CT} 8_{\mathrm{j}, \mathrm{m}}=\frac{1}{2} \cdot\left(\mathrm{CT} 5_{\mathrm{j}, \mathrm{m}}-\mathrm{CT} 6_{\mathrm{j}, \mathrm{m}}\right) \cdot \mathrm{e}^{\gamma 1_{\mathrm{j}, \mathrm{m}} \times \mathrm{x} 2_{\mathrm{j}}} \\
& \text { ВT9 }_{\mathrm{j}, \mathrm{m}}=\left(1+\frac{\mathrm{h} 1}{\mathrm{k} 1_{\mathrm{j}} \gamma 1_{\mathrm{j}, \mathrm{m}}}\right) \mathrm{BT}_{\mathrm{j}, \mathrm{m}}-(1 \\
& \left.-\frac{\mathrm{h} 1}{\mathrm{k} 1_{\mathrm{j}} \gamma 1_{\mathrm{j}, \mathrm{m}}}\right) \mathrm{BT} 7_{\mathrm{j}, \mathrm{m}} \\
& \text { СТ9 } 9_{j, \mathrm{~m}}=\left(1-\frac{\mathrm{h} 1}{\mathrm{k} 1_{\mathrm{j}} \gamma 1_{\mathrm{j}, \mathrm{m}}}\right) \mathrm{CT} 7_{\mathrm{j}, \mathrm{m}}-(1 \\
& \left.+\frac{\mathrm{h} 1}{\mathrm{k} 1_{\mathrm{j}} \gamma 1_{\mathrm{j}, \mathrm{m}}}\right) \mathrm{CT} 8_{\mathrm{j}, \mathrm{m}} \\
& \mathrm{BT} 10_{\mathrm{j}, \mathrm{m}}=\mathrm{BTO}_{\mathrm{j}, \mathrm{m}} \cdot \mathrm{CT} 9_{\mathrm{j}, \mathrm{m}}+\mathrm{CT} 0_{\mathrm{j}, \mathrm{m}} \cdot \mathrm{BT} 9_{\mathrm{j}, \mathrm{m}} \\
& E 2_{j}=U W_{j}\left[\left(\frac{x 1_{j}}{k 1_{j}}+\frac{1}{h 1}-\frac{x 1_{j}}{k 2_{j}}\right) \cdot A 3\right. \\
& \left.+\left(\frac{\mathrm{x} 3_{\mathrm{j}}-\mathrm{x} 2_{\mathrm{j}}}{\mathrm{k} 3_{\mathrm{j}}}+\frac{\mathrm{x} 2_{\mathrm{j}}}{\mathrm{k} 2_{\mathrm{j}}}+\frac{1}{\mathrm{~h} 2_{\mathrm{j}}}\right) \mathrm{Ts}_{\mathrm{j}}\right] \\
& \mathrm{BT} 11_{\mathrm{j}, \mathrm{m}}=\mathrm{h} 2_{\mathrm{j} \cdot} \cdot\left(\frac{\mathrm{BT} 10_{\mathrm{j}, \mathrm{m}} \cdot \mathrm{e}^{\gamma 3_{\mathrm{j}, \mathrm{m}} \times{ }^{\mathrm{j}} \mathrm{j}_{\mathrm{j}}}+\mathrm{CT} 9_{\mathrm{j}, \mathrm{m}} \cdot \mathrm{e}^{\gamma 3_{\mathrm{j}, \mathrm{m}} \times \mathrm{x} \mathrm{j}_{\mathrm{j}}}}{\mathrm{BT} 9_{\mathrm{j}, \mathrm{m}}}\right. \\
& \text { BT12 } 2_{\mathrm{j}, \mathrm{m}} \\
& =\frac{h 1 \cdot h 2_{j}}{k 1_{j} \gamma 1_{j, m}} \cdot\left(\frac{B T 10_{j, m} \cdot e^{\gamma 3_{j, m} \cdot x 3_{j}}+C T 9_{j, m} \cdot e^{\gamma 3_{j, m} \cdot x 3_{j}}}{B T 9_{j, m}}\right. \\
& E 3_{j}=U W_{j}\left[\left(\frac{x 1_{j}}{k 1_{j}}+\frac{1}{h 1}+\frac{x 2_{j}-x 1_{j}}{k 2_{j}}-\frac{x 2_{j}}{k 3_{j}}\right) \cdot A 3\right. \\
& \left.+\left(\frac{\mathrm{x} 3_{\mathrm{j}}}{\mathrm{k} 3_{\mathrm{j}}}+\frac{1}{\mathrm{~h} 2_{\mathrm{j}}}\right) \mathrm{Ts}_{\mathrm{j}}\right] \\
& \mathrm{P} 3_{\mathrm{j}}=\frac{\mathrm{UW}}{\mathrm{k} 3_{\mathrm{j}}} \cdot\left(\mathrm{A} 3-\mathrm{Ts} \mathrm{s}_{\mathrm{j}}\right) \\
& E 3_{j, m}=\frac{C T 9_{j, m} \cdot A 3_{m}+\frac{h 1}{k 1_{j} \cdot \gamma 1_{j, m}} \cdot T s_{j, m}}{B T 9_{j, m}}
\end{aligned}
$$

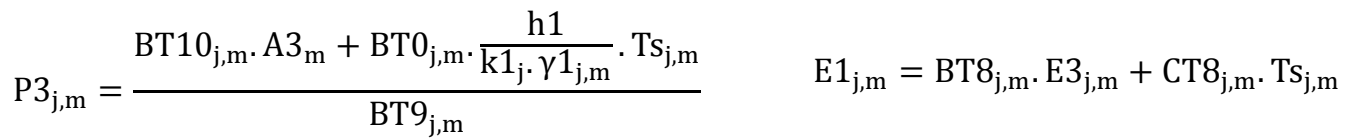

$$
\begin{aligned}
& \mathrm{P} 1_{\mathrm{j}, \mathrm{m}}=\mathrm{BT} 7_{\mathrm{j}, \mathrm{m}} \cdot \mathrm{E} 3_{\mathrm{j}, \mathrm{m}}+\mathrm{CT} 7_{\mathrm{j}, \mathrm{m}} \cdot \mathrm{Ts} \mathrm{s}_{\mathrm{j}, \mathrm{m}}
\end{aligned}
$$

